\title{
37. STRONTIUM ISOTOPIC RATIOS AS FLUID TRACERS IN MESSINIAN EVAPORITES OF THE TYRRHENIAN SEA (WESTERN MEDITERRANEAN SEA) ${ }^{1}$
}

\author{
Daniel W. Müller, ${ }^{2}$ Paul A. Mueller, ${ }^{2}$ and Judith A. McKenzie ${ }^{3}$
}

\begin{abstract}
Strontium isotopic ratios of gypsums recovered from upper Miocene (Messinian) evaporites at ODP Leg 107 Holes 652A, 653B, and 654A (Tyrrhenian Sea) are lower than expected. The values for the Messinian balatino-like gypsum, single gypsum crystals, and anhydrites range from 0.70861 to 0.70886 and are approximately $25 \times 10^{-5}$ less than would be expected for evaporites precipitated from Messinian seawater (0.70891-0.70902). Pre-evaporitic planktonic foraminifers from Hole $654 \mathrm{~A}$ show variable degrees of dolomitization and ${ }^{87} \mathrm{Sr} /{ }^{86} \mathrm{Sr}$ values that irregularly decrease upward from normal marine values approximately $81 \mathrm{~m}$ below the lowest evaporite occurrence. This suggests diagenetic alteration by advecting interstitial water with a low ${ }^{87} \mathrm{Sr} /{ }^{86} \mathrm{Sr}$ ratio or that the lower $\mathrm{Sr}$ isotopic ratios for the Messinian evaporites could have resulted from a greater influence of fresh water on the $\mathrm{Sr}$ isotopic composition of the desiccating Tyrrhenian Sea. Fluctuations of the ${ }^{87} \mathrm{Sr} /{ }^{86} \mathrm{Sr}$-ratio for evaporites in the sedimentary cycles recognized for Holes $653 \mathrm{~B}$ and $654 \mathrm{~A}$, the generally low $\mathrm{Sr}$ isotopic ratio of river water entering the Mediterranean Sea, and the presence of dwarf marine microfossils suggest that the ${ }^{87} \mathrm{Sr} /{ }^{86} \mathrm{Sr}$ ratio of the evaporites responded to hydrologic variations in a very restricted basin with variable rates of marine and fresh water input. The strontium isotopic ratios of the Messinian anhydrites from the proposed lacustrine sequence at Hole 652A fall in the same range as the marine evaporites from Holes 654A and $653 \mathrm{~B}$. This suggests a common or similar origin of the brines at the three locations.

The complex depositional and hydrologic conditions in the Mediterranean during the Messinian salinity crisis preclude the use of $\mathrm{Sr}$ isotopic values from the evaporites for stratigraphic correlation and dating. They are, however, very useful in the interpretation of the depositional history of the basin. General calculations assuming a closed system suggest that the ${ }^{87} \mathrm{Sr} /{ }^{86} \mathrm{Sr}$ ratio of Messinian seawater $(\sim 0.7090)$ could be reduced to that of the evaporites $(\sim 0.7087)$ by mixing with fresh water (e.g., Nile River) in times of $10^{4}$ to $10^{5} \mathrm{yr}$.
\end{abstract}

\section{INTRODUCTION}

A curve depicting the variation of ${ }^{87} \mathrm{Sr} /{ }^{86} \mathrm{Sr}$ in the Cenozoic oceans can be derived by compiling data from several recent studies (e.g., Burke et al., 1982; Koepnick et al., 1985; DePaolo and Ingram, 1985; De Paolo, 1986; Hess et al., 1986). Basically, the curve shows that the ${ }^{87} \mathrm{Sr} /{ }^{86} \mathrm{Sr}$ ratio of the oceans has been steadily increasing since the early Oligocene. Major variations of the ${ }^{87} \mathrm{Sr} /{ }^{86} \mathrm{Sr}$ ratio in seawater tend to occur gradually over a relatively long time period $\left(10^{6}\right.$ to $\left.10^{7} \mathrm{yr}\right)$ because the residence time of strontium in the oceans is large (4 m.y.; Turekian, 1969; Broecker and Peng, 1982) compared to the mixing time $(\sim 1000$ yr; Broecker et al., 1961). The ${ }^{87} \mathrm{Sr} /{ }^{86} \mathrm{Sr}$ in seawater is assumed to be uniform throughout the open ocean at any given time (Faure et al., 1965; Brass, 1976) and has been used for stratigraphic correlation of unaltered fossils (McKenzie et al., 1988), diagenetic marine carbonates (Saller, 1984; Swart et al., 1987; Aharon et al., 1987), and fish teeth (apatites, Staudigel et al., 1985).

The overall shape of the seawater curve is controlled by the balance between the ${ }^{87} \mathrm{Sr} /{ }^{86} \mathrm{Sr}$ composition of river influx (which has generally increased through geologic time because of the high average $\mathrm{Rb} / \mathrm{Sr}$ of the continental crust) and by the addition of strontium with low isotopic ratios ("unradiogenic" ratios) during hydrothermal alteration at mid-ocean ridges (Brass, 1976; Palmer and Elderfield, 1985). The influence of these two sources is buffered by the contribution of $\mathrm{Sr}$ from the dissolution of preexisting marine carbonates and evaporites. Rivers (0.7036-

\footnotetext{
${ }^{1}$ Kastens, K. A., Mascle, J., et al., 1990. Proc. ODP, Sci. Results, 107: College Station, TX (Ocean Drilling Program).

2 Department of Geology, University of Florida, 1112 Turlington Hall, Gainesville, FL 32611.

${ }_{3}^{3}$ Department of Geology, Swiss Federal Institute of Technology (ETH), 8092 Zürich, Switzerland.
}

0.7263; Eastin and Faure, 1970; Brass, 1976), brines (0.707020.70875; Faure and Jones, 1969; Zierenberg and Shanks, 1986), and groundwater (0.7045-0.718; Matter et al., 1987; Collerson et al., 1988) can have very different ${ }^{87} \mathrm{Sr} /{ }^{86} \mathrm{Sr}$ compositions depending on their origin and the lithologies through which they have passed (Brass, 1976; Holland, 1984). Therefore, the strontium isotopic ratio in carbonates, sulfates, and interstitial waters can be used to characterize depositional environments, and the solutions from which they precipitated (Faure and Jones, 1969; Jones and Faure, 1972; McNutt et al., 1984), as well as tracing pore fluids and estimating the extent of rock/water interaction in salt deposits (Land, 1987; Hovorka, 1987) or crystalline rocks (Kay and Darbyshire, 1986; Matter et al., 1987).

The cyclicity in the Upper Evaporite Formation deposited in the Mediterranean Basin during the late Miocene (Messinian) is well known (Ryan, Hsü, et al., 1973; Hsü, Montadert, et al., 1978). The deposition of shallow water sediments (Upper Evaporites) in a pre-evaporitic, deep basin has been interpreted as the result of recurring incursions of marine water through the Betic Strait with frequent evaporative drawdowns (Hsü et al., 1973; Müller and Hsü, 1987). Leg 107 recovered several hundred meters of the Upper Evaporites. This study utilizes the ${ }^{87} \mathrm{Sr} /{ }^{86} \mathrm{Sr}$ ratios of evaporites (gypsum and anhydrite) to evaluate depositional conditions and the effects of any early chemical reworking of the evaporites as a result of freshwater incursions in shallowing basins. Fresh waters could overprint the geochemical composition of the evaporites, including the development of nonmarine ${ }^{87} \mathrm{Sr} /{ }^{86} \mathrm{Sr}$ values. We use the term "chemical reworking" instead of diagenesis to point out that gypsum can be dissolved and reprecipitated shortly after its primary formation from a brine similar to the one from which it first precipitated. This reprecipitation causes an early lithification of the evaporites and forms a closed system which is less permeable to the penetration of less saline waters produced by cyclic environmental changes. Therefore, the $\mathrm{Sr}$ isotopic composition of the gyp- 
sum could reflect the value of the brines from which it crystallized even though there may have been a subsequent fresh water influence.

Initial measurements of ${ }^{87} \mathrm{Sr} /{ }^{86} \mathrm{Sr}$ ratios in Messinian evaporites from the Mediterranean Basin by Clauer (1976) suggested the potential of the method. At that time, the value of ${ }^{87} \mathrm{Sr} /{ }^{86} \mathrm{Sr}$ for late Miocene seawater was not precisely known and stratigraphic correlation was impossible. Marked increases in the precision of ${ }^{87} \mathrm{Sr} /{ }^{86} \mathrm{Sr}$ measurements and the resulting seawater curve for the late Miocene indicate a resolution of $\sim 350,000 \mathrm{yr}$ for the method (DePaolo, 1986; McKenzie et al., 1988). The initial objective of this study was to utilize the ${ }^{87} \mathrm{Sr} /{ }^{86} \mathrm{Sr}$ of the evaporites to constrain the depositional age of these Messinian sediments. Despite the fact that several previous studies suggested a strong freshwater influence and diagenetic overprint on the Upper Evaporites (Fontes et al., 1973a, b; Pierre 1974, 1982; Clauer, 1976; Ricchiuto and McKenzie, 1978), it was anticipated that some of the gypsum and anhydrite of the Tyrrhenian Basin may have retained a late Miocene marine $\mathrm{Sr}$ isotopic signal because the upper evaporites of the western Mediterranean, in general, were formed from marine brines (Kushnir, 1982). In addition, high resolution measurements should also be able to distinguish seawater variations from those associated with chemical reworking or later diagenesis of the evaporites. In terms of evaluating late diagenetic processes, the ${ }^{87} \mathrm{Sr} /{ }^{86} \mathrm{Sr}$ ratio has several advantages over stable isotopic systems. These include a uniform distribution of ${ }^{87} \mathrm{Sr} /{ }^{86} \mathrm{Sr}$ in the open ocean (Brass, 1976), no fractionation due to temperature or salinity differences, and no fractionation by biological activity (Elderfield, 1986). Additionally, it can be reasonably assumed that ${ }^{87} \mathrm{Sr} /{ }^{86} \mathrm{Sr}$ values in rivers emptying into the Mediterranean Basin since the late Miocene are similar to modern values (Albarède and Michard, 1987) because the composition of the rocks in the drainage areas have not changed significantly since the late Miocene.

The following questions were posed for this study: (1) Does the proposed marine gypsum/anhydrite from Holes $653 \mathrm{~B}$ and $654 \mathrm{~A}$ have a marine $\mathrm{Sr}$-isotopic ratio and if so, where do these values fall on the seawater curve? (2) How rapid was the evaporite deposition (e.g., $\sim 600,000 \mathrm{yr}$; twice our ${ }^{87} \mathrm{Sr} /{ }^{86} \mathrm{Sr}$ resolution)? (3) Do the proposed lacustrine evaporites from Hole $652 \mathrm{~A}$ carry a $\mathrm{Sr}$ isotopic signature of a brine different from that which formed the gypsums at Holes 653B and 654A? and (4) Does the Tyrrhenian basin have an unique strontium-isotope signal or is it comparable to other Mediterranean basins?

\section{METHODOLOGY}

Thin sections of some samples were made in order to evaluate the depositional features of the evaporites and to select samples for isotopic analyses. Samples were powdered by abrading $\sim 10 \mathrm{mg}$ of gypsum using a carbide-tipped dental drill in order to minimize carbonate and clay contamination. The samples were also examined by X-ray diffraction techniques to confirm their mineralogy. Gypsum samples were dissolved in distilled water. The sample solutions were filtered and the volume reduced. Then $2 \mathrm{~mL}$ of $6 \mathrm{~N} \mathrm{HCl}$ were added to convert the sample into chlorides. This step is repeated after desiccation which is ultimately followed by dissolution in $250 \mu \mathrm{L} 2 \mathrm{~N} \mathrm{HCl}$ and loading onto standard Dowex $50 \times 12$ ion exchange columns. Dolomites were dissolved as bulk samples using $0.5 \mathrm{~N} \mathrm{HCl}$. The solution was filtered and the volume also reduced to $250 \mu \mathrm{L}$ before loading on the exchange columns. Planktonic foraminifers were picked from the $>150-\mu \mathrm{m}$ size fraction and washed several times in distilled water in an ultrasonic cleaner; the liquid was decanted and the sample was dried. The carbonate was dissolved using $0.25 \mathrm{~N} \mathrm{HCl}$ to minimize leaching of strontium from non-carbonate materials (e.g., clay minerals). Sample volume was also reduced to $250 \mu \mathrm{L}$ for ion exchange. All samples were then eluted in $2 \mathrm{~N} \mathrm{HCl}$ and evaporated to dryness. The $\mathrm{Sr}$ fraction was then loaded either on a single oxidized Ta filament or on a single Re filament with $\mathrm{TaCl}_{2}$ in $\mathrm{HCl}$ and $\mathrm{H}_{3} \mathrm{PO}_{4}$. Isotopic ratios were measured on a VG Isomass 354 triple collector mass spectrometer in the dynamic mode with mass fractionation normalized to an ${ }^{87} \mathrm{Sr} /{ }^{86} \mathrm{Sr}$ ratio of 0.1194 . The blank for the entire procedure is less then $1 \mathrm{ng}$ total strontium. Analytical precision is $\pm 2 \times$ $10^{-5}$, as measured by the two sigma value of 76 runs of a standard strontium carbonate (SRM 987). Our value for SRM 987 is 0.710235 (n $=76$ ) and modern Mediterranean seawater 0.70916 (average of three measurements from the Bannock Basin, eastern Mediterranean: $600 \mathrm{~m}$ $=0.70918 ; 2000 \mathrm{~m}=0.70913 ; 3306 \mathrm{~m}=0.70916)$. Approximate modern seawater from the Pacific Ocean was obtained by measuring USGS sample MSW-1, an informally distributed carbonate from a giant modern bivalve from Eniwetok, which we measure to have a mean ${ }^{87} \mathrm{Sr} /{ }^{86} \mathrm{Sr}$ ratio of 0.709175 . All ${ }^{87} \mathrm{Sr} /{ }^{86} \mathrm{Sr}$ values from other sources are corrected to an SRM 987 value of 0.710235 .

For atomic absorption spectroscopy $(\mathrm{Sr}, \mathrm{Ca})$, gypsum/anhydrite samples were dissolved in distilled water in order to selectively dissolve the sulfate minerals and quantitatively measured using a Perkin-Elmer 403 Atomic Absorption Spectrophotometer.

For stable isotopic analysis, the foraminifers were hand picked and roasted in vacuo for $60 \mathrm{~min}$ at $400^{\circ} \mathrm{C}$ to remove organic material. The reaction of the carbonates and the production of $\mathrm{CO}_{2}$ gas (after McCrea, 1950) at $70^{\circ} \mathrm{C}$ occurred on-line using an automated carbonate extraction apparatus. Samples were reacted in a common acid bath of $100 \% \mathrm{H}_{3} \mathrm{PO}_{4}$. The evolved gas was analyzed with a VG Isogas-PRISM triple collector mass spectrometer. The errors are $\pm 0.08 \%$ for $\delta^{13} \mathrm{C}$ and $0.1 \%$ for $\delta^{18} \mathrm{O}$.

The carbonate content of the marls was measured using a Coulomat 701 (Herrmann and Knake, 1973). The dolomite/calcite ratio was determined semiquantitatively by X-ray diffraction. The precisions for these latter methods are $\pm 5 \%$ and $\pm 10 \%$, respectively.

\section{STRATIGRAPHY AND SEDIMENTOLOGY}

Samples for this study were selected from Sites 652,653 , and 654 (Fig. 1). In the latter two holes, gypsum layers are intercalated with marine sediments, whereas, in Hole 652A, anhydrite occurs as discrete layers in a marly to sandy sequence, probably
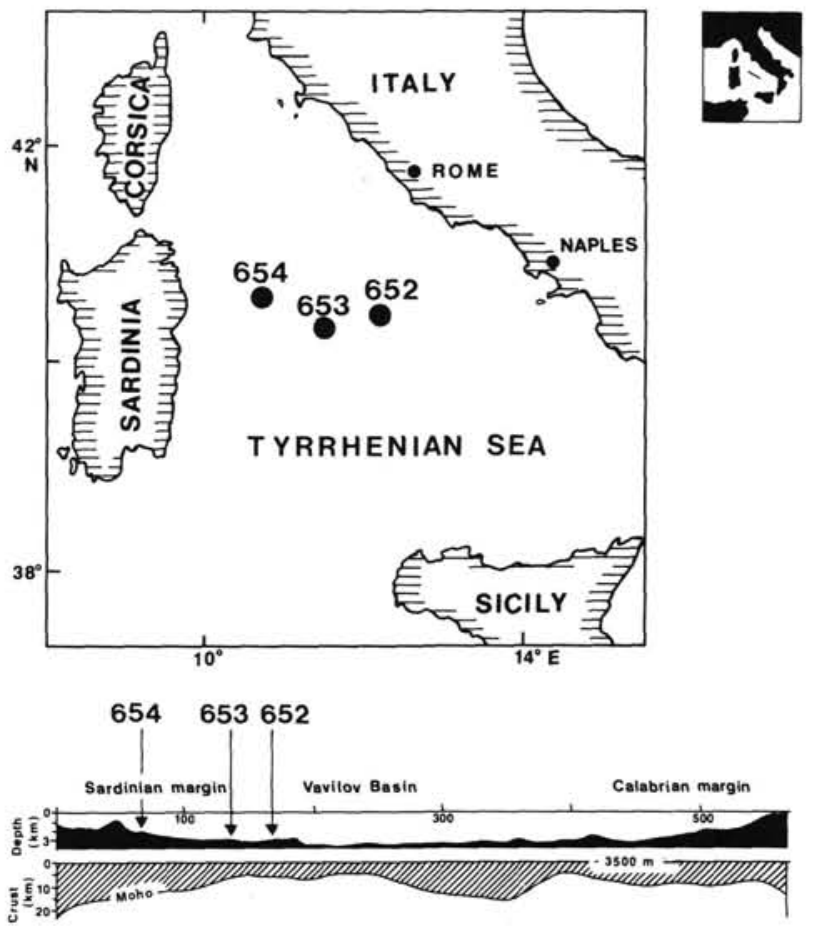

Figure 1. Upper Evaporites were recovered from ODP Sites 652, 653, and 654 which are located on the Sardinian continental margin in the northwestern Tyrrhenian Sea. Hole 654A penetrated the evaporites and recovered pre-evaporitic marine nannofossil chalk. More than $500 \mathrm{~m}$ of lacustrine sediments with anhydrite nodules of probable Messinian age were cored in Hole 652A. Site 653 is a reoccupation of DSDP Site 132. 
deposited in a lacustrine environment. In order to evaluate the depositional environment, different forms of evaporites were selected, such as anhydrite nodules, balatino-type gypsum (finely laminated gypsum and clay-rich layers), gypsum-bearing siltstones, and secondary gypsum crystals from veins (Table 1).

\section{Hole 654A}

In Hole $654 \mathrm{~A}$, located on the upper continental margin of Sardinia $\left(40^{\circ} 34^{\prime} \mathrm{N}, 10^{\circ} 41^{\prime} \mathrm{E}\right)$ (Fig. 1), a sequence of $243 \mathrm{~m}$ of Pliocene-Pleistocene sediments overlies a series of evaporitic to open marine, Messinian-Tortonian sediments (243-406 mbsf). These sequences are underlain by a few meters of glauconitic sands which are transgressive upon continental deposits. This hole offered the best opportunity to study the ${ }^{87} \mathrm{Sr} /{ }^{86} \mathrm{Sr}$ ratio in late Miocene sediments because the available magnetostratigraphy provides good chronostratigraphic control (see Channell et al., this volume), planktonic and benthonic foraminiferal assemblages, and nannofossils between Messinian gypsum deposits indicate that from time to time marine conditions dominated (Kastens, Mascle, et al., 1987), and the Messinian sediments are underlain by a marine Tortonian unit.

All of the studied evaporite samples are from lithologic Unit 2 (Cores 654A-27R-1, $3 \mathrm{~cm}$, to 654A-36R-1, $110 \mathrm{~cm}$; 242.7$312.6 \mathrm{mbsf}$ ). This Unit was further subdivided into five gypsumrich intervals, separated by six intervals of less indurated sediments. Planktonic foraminifers and nannofossils occur mainly in these calcareous, gypsum-poor sediments. Fine scale (millimeter to centimeter) grading in the gypsiferous and calcareous beds was attributed to turbiditic deposition and/or resuspension effects. Evidence of bottom current activity is manifested throughout the unit. The environment was interpreted as mostly marine, with a stratified water column and gypsum growth on the bottom. The sulfate-rich layers appear to have been lithified early, whereas the softer, gypsum-poor sediments between the gypsum-rich intervals remain unlithified and underwent postdepositional compaction. These eleven intervals are represented by nine samples (Table 1).

To test if the pre-evaporitic sediments have contemporaneous, late Miocene, ${ }^{87} \mathrm{Sr} /{ }^{86} \mathrm{Sr}$ seawater values or a diagenetic overprint, the ${ }^{87} \mathrm{Sr} /{ }^{86} \mathrm{Sr}$ ratios of dolomitic horizons within nannofossil ooze and planktonic foraminifers from lithologic Unit 4 (Cores $654 \mathrm{~A}-40 \mathrm{R}-1,7.5 \mathrm{~cm}$, to $654 \mathrm{~A}-45 \mathrm{R}-5,145 \mathrm{~cm} ; 348.9-403.9 \mathrm{mbsf}$ ) were measured. Also, seven planktonic foraminifer samples were picked from latest Tortonian/earliest Messinian light gray, strongly bioturbated, nannofossil chalk/ooze and silty calcareous chalk. In the early Messinian sediments (654A-41R/40R), bioturbation is only minor; pyritized worm burrows and foraminifer shells filled with pyrite and a slight petroliferous smell were recognized. These sediments were thought to be time equivalent to the Tripoli Formation. Two laminated mudstones, with dolomite as the only carbonate component, were analyzed for their ${ }^{87} \mathrm{Sr} /{ }^{86} \mathrm{Sr}$ ratios $(654 \mathrm{~A}-40 \mathrm{R}-1,41$ and $91 \mathrm{~cm})$.

\section{Site 653}

Site 653 is located on the eastern rim of the Cornaglia Basin in the western Tyrrhenian $\left(40^{\circ} 15^{\prime} \mathrm{N}, 11^{\circ} 26^{\prime} \mathrm{E}\right.$; Fig. 1). This site is a reoccupation of DSDP Leg 13, Site 132. Hole 653B is characterized by open marine, hemipelagic to pelagic, Pliocene-Quaternary sedimentation from 0 to 216 mbsf. Messinian sediments of restricted marine to evaporitic and subaerial(?) origin were cored from 216 to 264.3 mbsf (Kastens, Mascle, et al., 1987). The three measured gypsum samples are from Unit 2, which corresponds to Unit 3 of DSDP Site 132 (Table 1).

A detailed scenario for the evaporitic sequence of this hole is described in Kastens, Mascle, et al. (1987, p. 632-633). The main points pertaining to the interpretation of the strontium data are:
1. The cored sediments appear to represent a transgressive cycle within a shallow, semi-restricted to restricted, marginalmarine environment,

2. Iron oxides and sulfur from the base of Hole 653B are a by-product of chemical weathering. The reduced iron was transported by acidic groundwaters which emerged as springs along the shoreline. This was the depositional environment for the lowermost ( $263.89 \mathrm{mbsf}$ ) gypsum. Modern supratidal to continental environments of restricted hypersaline embayments or continental saline lacustrine environments in Australia (Ferguson et al., 1983; Teller et al., 1982), have been proposed as analogues,

3. Subsequent deposition of stromatolites interbedded with red mud is the first indication of transgressive conditions. The second sample (236.2 mbsf) consists of gypsum crystals which grew as a mush in the near-surface, gray, dolomitic mud of an intertidal facies, and

4. Marine nannofossil and impoverished planktonic foraminifer assemblages suggest restricted marine communication. In this semi-marine basin, light brown gypsum nodules with chicken wire texture were formed. The third sample ( $225.97 \mathrm{mbsf}$ ) represents this lithofacies.

\section{Hole 652A}

Hole $652 \mathrm{~A}\left(40^{\circ} 21^{\prime} \mathrm{N}, 12^{\circ} 8^{\prime} \mathrm{E}\right)$ was drilled on the lowermost, eastern Sardinian continental margin on thinned continental crust in the central Tyrrhenian Sea (Fig. 1). The sediments are dominated by Plio/Pleistocene, hemipelagic, marine sediments from 0 to $188 \mathrm{mbsf}$, and a very thick, barren, gypsiferous, calcareous, sandy mud and mudstone interbedded with minor evaporites (gypsum and anhydrite) from 188 to $721 \mathrm{mbsf}$, most probably representing a lacustrine Messinian sequence. The samples are from subunits IVb (Cores 652A-31R to $-35 \mathrm{R}$ : 286.3-334.7 mbsf) and Va (Cores 652A-37R to 652-72R-2: 344.8-683.5 mbsf). Subunit IVb consists of reversely graded alternations of gypsum- and carbonate-bearing, sandy silts or sands and calcareous clays or muds. Subunit $\mathrm{Va}$ is characterized by a monotonous succession of numerous, centimeter thick, olive gray to dark gray sequences of well-graded and cross-bedded gypsum and carbonate bearing sand or sandy silt, and well-layered clays or muds. The rhythmic repetition of numerous centimeter-thick sequences was tentatively interpreted as reflecting tempestite deposition and bottom current reworking of sediments. The environment was apparently characterized by variable salinity and periods of high productivity. Seven second-order cycles with increasing amounts of sulfate toward the top of each cycle were described. The samples are from cycles 2,3, and 7, and Subunit $\mathrm{IVb}$ (Table 1). Subunits Va and IVb are separated by a 5-m-thick pebble horizon (subunit IVc) which may represent a fluviatile or beach environment.

\section{GEOCHEMICAL RESULTS}

The ${ }^{87} \mathrm{Sr} /{ }^{86} \mathrm{Sr}$ ratios of the evaporites show a relatively wide variation from 0.70861 to 0.70886 (Fig. 2A). Variations of the Sr-isotopic ratios in Hole $654 \mathrm{~A}$ occur within $1.2-20 \mathrm{~m}$ of each other and are due to alternate sampling of gypsum-poor and gypsum-rich intervals (Fig. 3). The Sr-isotopic ratios of all measured evaporites ( $\mathrm{Sr}$ values) are lower than their assumed contemporaneous seawater $(0.70891$ and 0.70902 ; McKenzie et al., 1988; Hodell et al., 1989) and there is no distinguishable difference in ratios between anhydrite and gypsum. In Hole 654A, a decrease of the ${ }^{87} \mathrm{Sr} /{ }^{86} \mathrm{Sr}$ ratios occurs between 300 and 290 mbsf from 0.70885 to 0.70872 and, in Hole 653, a similar decrease occurs between 236 and 226 mbsf.

The ${ }^{87} \mathrm{Sr} /{ }^{86} \mathrm{Sr}$ ratios of the sulfates are independent of their $\mathrm{Sr} / \mathrm{Ca}$ ratio (Fig. 2A; Table 2 ). The $\mathrm{Sr} / \mathrm{Ca}$ variability is large within the same depth ranges in the individual holes (Fig. 2B). 
Table 1. Depth, sedimentary characteristics, and ${ }^{87} \mathrm{Sr} /{ }^{86} \mathrm{Sr}$ ratios of the evaporites from Leg 107, Holes 654A, 653B, and 652A.

\begin{tabular}{|c|c|c|}
\hline Sample & $\begin{array}{l}\text { Depth } \\
\text { (mbsf) }\end{array}$ & Sedimentary characteristics \\
\hline 654A-36R-1, 110 & 311.1 & $\begin{array}{l}\text { Gypsum-rich interval } 5 \text { (310-311.1 mbsf). Base of the interval } \\
\text { and also of Unit } 2 \text {, just above an unconformity. Very finely } \\
\text { laminated medium to dark gray balatino-gypsum dominates } \\
\text { this interval. The color is clearly darker than in the following } \\
\text { intervals. }\end{array}$ \\
\hline 654A-35R-1, 40 & 300.41 & $\begin{array}{l}\text { Gypsum-poor interval } 4 \text { (300.1-309.95 mbsf). The sample } \\
\text { occurred in a pocket of secondary gypsum in a gypsiferous } \\
\text { and calcareous mudstone. Pyrite and secondary gypsum } \\
\text { crystals are abundant. The latter, showing typical twinning, } \\
\text { were picked from the sediment, washed and then analyzed. }\end{array}$ \\
\hline 654A-34R-1, 99 & 291.6 & $\begin{array}{l}\text { Gypsum-rich interval } 4(290.74-295.8 \text { mbsf) which is dominated } \\
\text { by white to yellowish } 0.5-1 \mathrm{~cm} \text { thick laminae. }\end{array}$ \\
\hline 654A-33R-1, 61 & 288.21 & $\begin{array}{l}\text { Gypsum-poor interval } 3 \text { ( } 287.6-290.6 \text { mbsf). Sample is a crystal- } \\
\text { line gypsum. Most of the interval comprises alternations of } \\
\text { centimeter-thick well layered dark gray calcareous muds with } \\
\text { very fine gypsiferous laminae. White marls with abundant } \\
\text { nannofossils occur in Section } 654 \mathrm{~A}-33 \mathrm{R}-1,112-130 \mathrm{~cm} \text {. }\end{array}$ \\
\hline $654 \mathrm{~A}-31 \mathrm{R}-1,121$ & 277.51 & $\begin{array}{l}\text { Gypsum-rich interval } 3 \text { ( } 277.3-287.6 \text { mbsf). The gypsum is a fine } \\
\text { grained laminated alabastrine (balatino) type. }\end{array}$ \\
\hline 654A-31R-1, 5 & 276.35 & $\begin{array}{l}\text { Gypsum-poor interval (276.3-277.3 mbsf). The sample consists } \\
\text { of large gypsum crystals with swallow tail twinning. Normal } \\
\text { graded units composed of sand and silt which pass up into } \\
\text { poorly calcareous silty mud. A 10-cm thick microbreccia at } \\
\text { the base of this interval is possibly of eolian origin. }\end{array}$ \\
\hline 654A-30R-1, 87 & 272.14 & $\begin{array}{l}\text { Gypsum-rich interval } 2 \text { (272-276.1 mbsf). Sample is part of a } \\
\text { pure balatino-type finely laminated gypsum. }\end{array}$ \\
\hline 654A-29R-2, 16 & 263.36 & $\begin{array}{l}\text { Gypsum-rich interval } 1 \text { ( } 253.5-264.42 \text { mbsf). Sample occurs in } \\
\text { weakly consolidated gypsiferous and dolomitic mud, and } \\
\text { graded gypsiferous silts and muds which dominate the } \\
\text { interval. Micro-cross lamination, ripple and flaser structures } \\
\text { were noted. Subvertical fractures infilled with gypsiferous } \\
\text { silty sand record physical diagenesis. Concretions of selenitic } \\
\text { gypsum were interpreted as chemical diagenesis. }\end{array}$ \\
\hline 654A-27R-1, 29 & 243.09 & $\begin{array}{l}\text { Gypsum-rich interval } 1 \text { ( } 242.7-253.5 \text { mbsf). Sample is from top } \\
\text { of Unit } 2 \text {. It is again fine grained alabastrine balatino-type } \\
\text { gypsum. The laminae between the gypsum can often be very } \\
\text { calcareous, sometimes containing calcareous nannofossils. }\end{array}$ \\
\hline 653B-28X-CC, 29 & 263.89 & $\begin{array}{l}\text { Dark gray laminated gypsum from the bottom of Hole B. The } \\
\text { host and overlying sediments are calcareous clays/muds of } \\
\text { grayish, brownish, and yellowish colors. In the overlying } \\
\text { Core } 653 \mathrm{~B}-27 \mathrm{X} \text { occur at the base putrid-smelling brilliant } \\
\text { yellow and red mud and silts, containing iron oxides, sulfur, } \\
\text { and sulfates. }\end{array}$ \\
\hline 653B-26X-1, 89 & 236.2 & $\begin{array}{l}\text { Picked gypsum crystals with dark inclusions (similar to Kastens, } \\
\text { Mascle, et al., 1987, Fig. 10). The host sediment is a gray } \\
\text { calcareous gypsiferous mud progressively enriched in dolo- } \\
\text { mite downsection with fewer nannofossils. }\end{array}$ \\
\hline 653B-25X-1, 24 & 225.97 & $\begin{array}{l}\text { Light brown gypsum nodules with chicken wire texture. Matrix } \\
\text { between nodules has wavy laminations. The layering is } \\
\text { amplified by very thin dark brown intercalations (see Kas- } \\
\text { tens, Mascle, et al., 1987, Fig. 8). }\end{array}$ \\
\hline $652 A-70 R-4,116$ & 668.76 & $\begin{array}{l}\text { Sedimentary-cycle } 7 \text { (Core } 652 \mathrm{~A}-70 \mathrm{R} ; 663.1-672.8 \mathrm{mbs} \text { ). Sample } \\
\text { is a grey laminated mudstone with clay horizons and displa- } \\
\text { cively grown anhydrite nodules. A minor amount of dolo- } \\
\text { mite is also present. The analyzed powder was drilled from } \\
\text { the nodular horizon. }\end{array}$ \\
\hline $652 \mathrm{~A}-44 \mathrm{R}-3,79$ & 425.59 & $\begin{array}{l}\text { Sedimentary cycle } 3 \text { (Core } 652 \mathrm{~A}-44 \mathrm{R}, 412.1-421.8 \mathrm{mbsf} \text { ). The } \\
\text { drilled sample originates from a white anhydrite horizon in a } \\
\text { gray sandy laminated mudstone with displacively grown } \\
\text { white anhydrite nodules (see Kastens, Mascle, et al., 1987, } \\
\text { Fig. 13). }\end{array}$ \\
\hline $652 \mathrm{~A}-42 \mathrm{R}-3,80$ & 406.2 & $\begin{array}{l}\text { Sedimentary cycle } 2 \text { (Cores } 652 \mathrm{~A}-38 \mathrm{R} \text { to }-43 \mathrm{R}, 354-412.1 \mathrm{mbsf} \text { ). } \\
\text { This anhydrite is a larger nodule in the gypsiferous calcare- } \\
\text { ous mudstone. }\end{array}$ \\
\hline 652A-38R-3, 111 & 367.81 & Sedimentary cycle 2 (Cores $652 \mathrm{~A}-38 \mathrm{R}$ to $-43 \mathrm{R}, 354-412.1 \mathrm{mbsf}$ ). \\
\hline & 366.77 & $\begin{array}{l}\text { Both samples were deposited within two of the several described } \\
\text { sequences (1-25 cm thick). A single sequence starts with a } \\
\text { sharp, often scoured black gray basal contact, overlain by } \\
\text { gypsum-bearing sands and silts, well graded, often bedded } \\
\text { and laminated, followed by olive layered clays and muds, } \\
\text { and ends with crystalline anhydrite with chicken wire texture, } \\
\text { like the two measured samples. }\end{array}$ \\
\hline $652 \mathrm{~A}-33 \mathrm{R}-3,46$ & 318.76 & $\begin{array}{l}\text { Lithologic subunit IVb ( } 286.3-334.7 \text { mbsf }) \text {. The sample is a } \\
\text { grayish brown halite and gypsum-bearing sandy siltstone. In } \\
\text { this subunit reversely graded sequences, water-escape struc- } \\
\text { tures, synsedimentary microfaults, and microbreccias were } \\
\text { recognized. The first occurrence of crystals of authigenic } \\
\text { calcium sulfates and cubic dissolution molds were recovered } \\
\text { in Cores } 652 \mathrm{~A}-33 \mathrm{R} \text { to }-35 \mathrm{R} \text {. }\end{array}$ \\
\hline
\end{tabular}



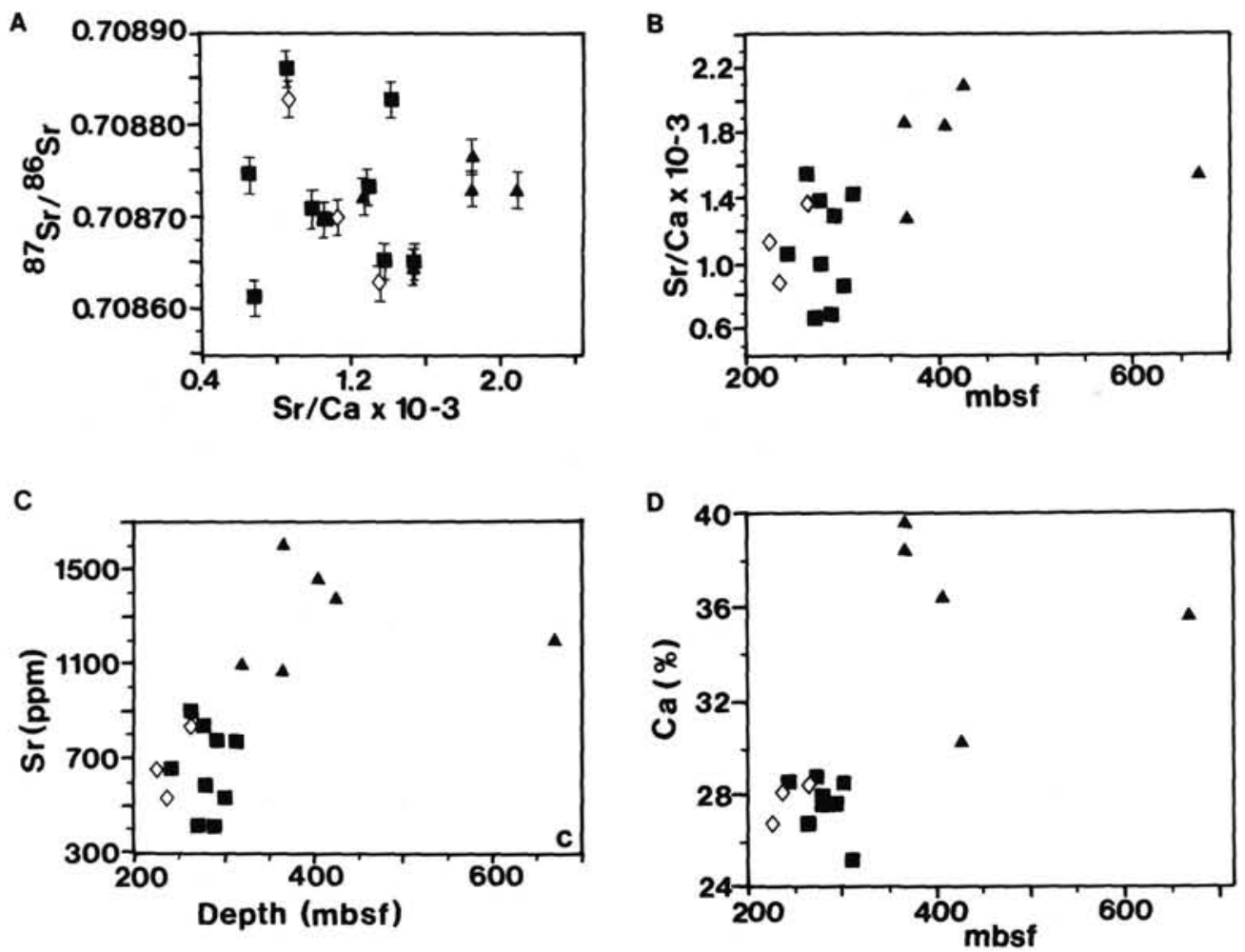

Figure 2. A. The variability of the $\mathrm{Sr} / \mathrm{Ca}$ ratio $(\mathrm{mmol} / \mathrm{L})$ and the ${ }^{87} \mathrm{Sr} /{ }^{86} \mathrm{Sr}$ ratios are high. No real trend in the figure is evident. B. The $\mathrm{Sr} / \mathrm{Ca}$ ratio has no close relation with depth. The variability at the same depth (e.g., $300 \mathrm{mbsf}$ ) is high. C. The variability of $\mathrm{Sr}$ content in all evaporites is relatively high. In Hole $652 \mathrm{~A}$ (filled triangles) changes occur within the same cycle from one sequence to the other. The low $\mathrm{Sr}$ content of the anhydrites and the gypsums suggest a chemical reworking of the gypsum and a dehydration of the anhydrites from gypsums similar to those of Holes 653B (open diamonds) and 654A (filled squares). D. The variability of $\mathrm{Ca}$ in the anhydrites of Hole $652 \mathrm{~A}$ is large, whereas it is relatively constant in gypsum samples from Holes 653B and 654A.

Table 2. Sr/Ca and ${ }^{87} \mathrm{Sr} /{ }^{86} \mathrm{Sr}$ ratios of the measured evaporites of Leg 107.

\begin{tabular}{llccccc}
\hline \multicolumn{1}{c}{ Sample } & $\begin{array}{c}\text { Depth } \\
\text { (mbsf) }\end{array}$ & $\begin{array}{c}\mathrm{Sr} \\
(\mathrm{ppm})\end{array}$ & $\begin{array}{c}\mathrm{Ca} \\
(\%)\end{array}$ & $\begin{array}{c}\mathrm{Sr} / \mathrm{Ca} \times 10^{-3} \\
(\mathrm{mmol} / \mathrm{L})\end{array}$ & ${ }^{87} \mathrm{Sr} /{ }^{86} \mathrm{Sr}$ & $\begin{array}{c}\text { Standard } \\
\text { error }^{2}\end{array}$ \\
\hline 652A-33R-3, 46 & 318.76 & 1099 & & & 0.708780 & \pm 12 \\
652A-38R-3, 7-8 & 366.77 & 1070 & 38.5 & 1.269 & 0.708745 & \pm 18 \\
$652 \mathrm{~A}-38 \mathrm{R}-3,111$ & 367.81 & 1603 & 39.7 & 1.845 & 0.708722 & \pm 19 \\
652A-42R-3, 80 & 406.2 & 1470 & 36.4 & 1.846 & 0.708730 & \pm 10 \\
652A-44R-3, 79 & 425.59 & 1382 & 30.2 & 2.088 & 0.708725 & \pm 16 \\
652A-70R-4, 116 & 668.76 & 1194 & 35.5 & 1.536 & 0.708641 & \pm 16 \\
653B-25X-1, 24 & 225.97 & 656 & 26.6 & 1.124 & 0.708703 & \pm 18 \\
653B-26X-1, 89 & 236.2 & 533 & 28.0 & 0.868 & 0.708829 & \pm 14 \\
653B-28X-CC, 29 & 263.89 & 841 & 28.3 & 1.353 & 0.708623 & \pm 12 \\
654A-27R-1, 29 & 243.09 & 656 & 28.5 & 1.051 & 0.708729 & \pm 20 \\
654A-29R-2, 16 & 263.36 & 902 & 26.8 & 1.539 & 0.708627 & \pm 20 \\
654A-30R-1, 87 & 272.14 & 410 & 28.7 & 0.652 & 0.708748 & \pm 20 \\
654A-31R-1, 5 & 276.35 & 841 & 27.9 & 1.374 & 0.708652 & \pm 16 \\
654A-31R-1, 121 & 277.51 & 595 & 27.6 & 0.984 & 0.708717 & \pm 18 \\
654A-33R-1, 61 & 288.21 & 410 & 27.6 & 0.678 & 0.708605 & \pm 18 \\
654A-34R-1, 99 & 291.6 & 779 & 27.6 & 1.288 & 0.708733 & \pm 12 \\
654A-35R-1, 40 & 300.41 & 533 & 28.5 & 0.854 & 0.708866 & \pm 16 \\
654A-36R-1, 110 & 311.1 & 779 & 25.2 & 1.414 & 0.708843 & \pm 12 \\
\hline
\end{tabular}

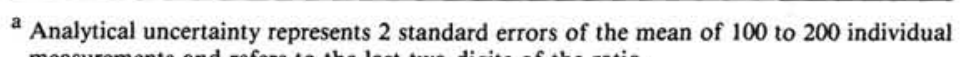
measurements and refers to the last two digits of the ratio.

The $\mathrm{Sr}$ and $\mathrm{Ca}$ contents of the anhydrites in Hole 652A are generally greater than at Holes 653 and 654 and show fluctuations between cycles as well as within single cycles (Figs. 2C, -D). The occurrence of a pebble horizon at 340 mbsf in Hole 652A may have enhanced movement of a fluid with a lower $\mathrm{Sr}$ concentration from subunit IVb into the underlying Subunit Va, lowering the $\mathrm{Sr}$ content of the uppermost anhydrite of cycle 2 in Subunit Va (652A-38-3, 7-8 cm; Table 2). The gypsum samples from Holes 653B and 654A have relatively low $\mathrm{Sr}$ contents. The relatively low Sr contents of all the Leg 107 evaporites (410-902 ppm) compared to primary marine anhydrite and gypsum (15002300 ppm; Usdowski, 1973; Butler, 1973) suggest chemical re- 
working of the gypsum with loss of Sr. The values are too low for pristine marine gypsum (Usdowski, 1973), and the high variability of the ${ }^{87} \mathrm{Sr} /{ }^{86} \mathrm{Sr}$ ratios indicates that this reworking did not take place in a fluid with a constant ${ }^{87} \mathrm{Sr} /{ }^{86} \mathrm{Sr}$ ratio. If there had been constant marine conditions, there should be minimal variability. Because the phase transformation of gypsum to anhydrite occurs in a water saturated system via dissolution of the gypsum and precipitation of the anhydrite (Kushnir, 1982), the gypsum precursor of the Hole $652 \mathrm{~A}$ anhydrites must have had $\mathrm{Sr}$ contents higher than $1600 \mathrm{ppm}$, within the range of recent primary marine gypsum (1500-2300 ppm; Usdowski, 1973). The similar ${ }^{87} \mathrm{Sr} /{ }^{86} \mathrm{Sr}$ ratios of the anhydrites of Hole $652 \mathrm{~A}$ and the gypsum of Holes 653B and 654A suggest that the anhydrites are a dehydration product of gypsum which formed in brines similar to those of 653 and 654 , or the anhydrites were formed later from gypsum saturated fluids migrating from the region of these two holes. These scenarios both suggest a similar brine source for the crystallization or chemical reworking of the evaporites at all three sites.

With the magnetostratigraphic age control on the sediments of Hole $654 \mathrm{~A}$ (see Channell, et al., this volume), the ${ }^{87} \mathrm{Sr} /{ }^{86} \mathrm{Sr}$ ratio of the evaporites can be plotted vs. age and compared with the seawater curve (Fig. 3). The gypsum samples from Hole $654 \mathrm{~A}$ have generally lower $\mathrm{Sr}$ isotopic values than contemporaneous, late Miocene seawater. The gypsum values would suggest a Sr-isotope age between 19 and $11 \mathrm{Ma}$ (Fig. 4). This age is unreasonably old because the evaporites in Hole $654 \mathrm{~A}$ were deposited after the Tortonian/Messinian boundary, based on bio- and magnetostratigraphic correlations, at approximately 6.1 Ma. The underlying marine sediments and measured planktonic foraminifers (Tables 3 and 4) have low Sr-isotopic ratios which also suggest anomalous ages. Interestingly, large fluctuations in the Srisotopic values of the planktonic foraminifers and the ratios of the foraminifers and the first two overlying gypsum samples are similar. The average of the foraminifers $(0.70886)$ is within analytical error of the values for the two gypsums $(0.70885)$. The oldest gypsum horizon and the youngest marine foraminiferbearing, marly nannofossil ooze may be separated by an unconformity, which represents the loss of mostly pre-evaporitic Messinian sediments as well as the Lower Evaporites. Based on magnetostratigraphic interpretations, the lowermost balatinogypsum from Hole 654A was most probably deposited during the uppermost normal polarity of Chron 5 , and the underlying marine sediments were deposited during the upper part of reversed interval of Chron 6 (Channell et al., this volume).

Carbonate and XRD analyses of the Tortonian/Messinian nannofossil chalk, Hole 654A: $348.9-403.9 \mathrm{mbsf}$, reveal the presence of two, distinct, dolomite-rich horizons (348.6-358.3 mbsf and 389.1-402.3 mbsf; Table 5). The dolomite enrichment between 348.6 and 358.3 mbsf coincides with the presence of laminated mudstone in the top of Unit IV (348.9-403.9 mbsf; Section $654 \mathrm{~A}-40 \mathrm{R}-1)$ and in the overlying Unit III (312.6-348.9 mbsf). Strontium isotopic analyses of two dolomite samples from the top of the upper horizon fall in the same range as the values of the foraminifers and the gypsum samples (Fig. 3). Comparison of these values with the seawater curve would sug-

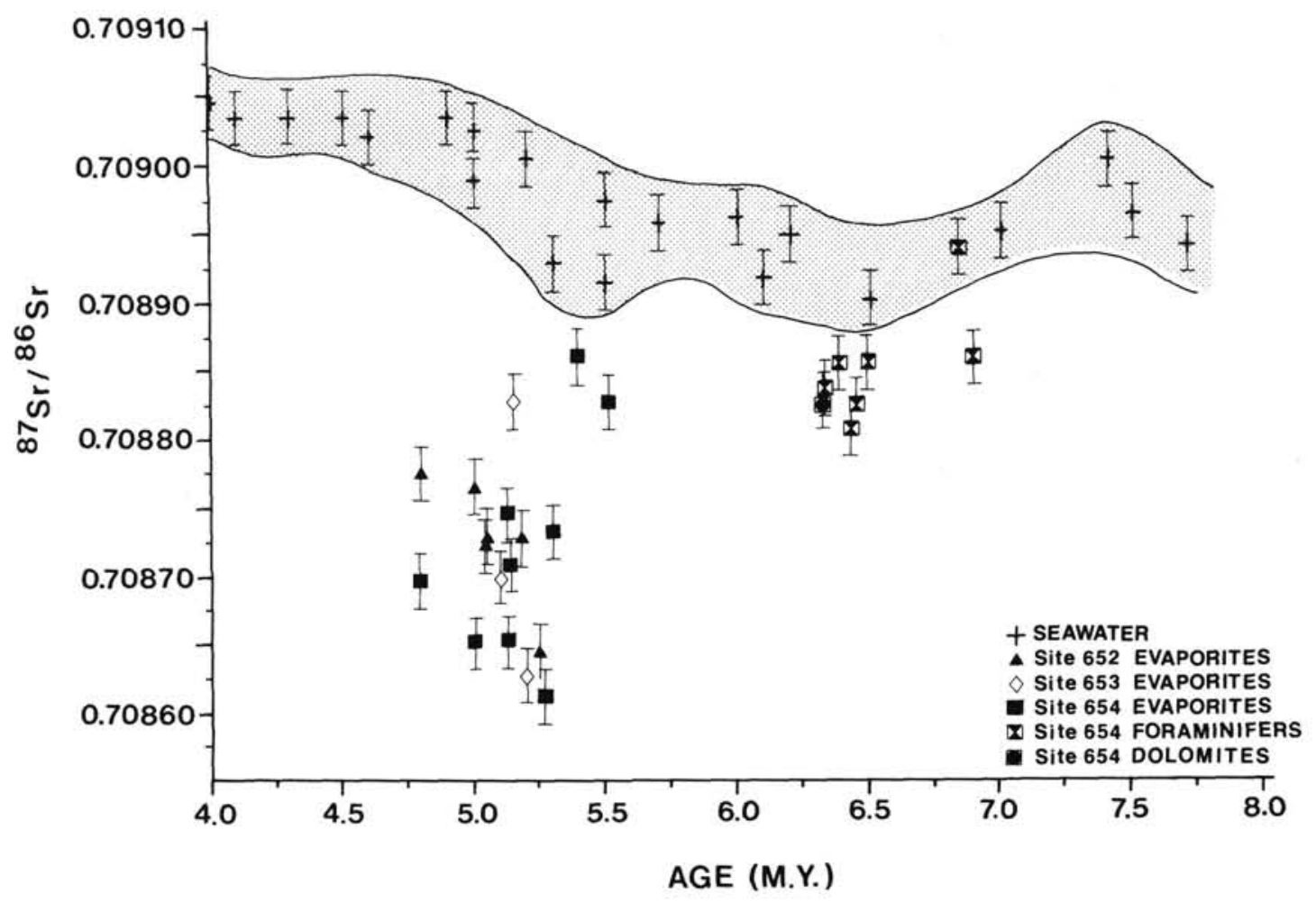

Figure 3. The magnetostratigraphic control on Hole 654A (see Channell et al., this volume) permits the comparison of the $\mathrm{Sr}$ isotopic ratios with the contemporaneous seawater curve. Late Tortonian and early Messinian planktonic foraminifers and two dolomitic mudstones are highly variable and deviate from the seawater values. This is interpreted as an early diagenetic overprint during dolomitization of the pre-evaporitic sediments. The two lowermost evaporites have similar values and were probably deposited as the dolomitization occurred. The younger evaporites deviate clearly from seawater values. The results of Holes $652 \mathrm{~A}$ and $653 \mathrm{~B}$ were plotted based on the assumption that these evaporites are basically timeequivalent to those of Hole 654A. The $\mathrm{Sr}$ isotopic ratios of Hole $652 \mathrm{~A}$ increase with decreasing age. Seawater values (dotted area) are from Koepnick et al. (1985), DePaolo and Ingram (1985), Hess et al. (1986), and DePaolo (1986) and are corrected to our SRM $987=0.710235$. Analytical error bar is $\pm 2 \times 10^{-5}$. 


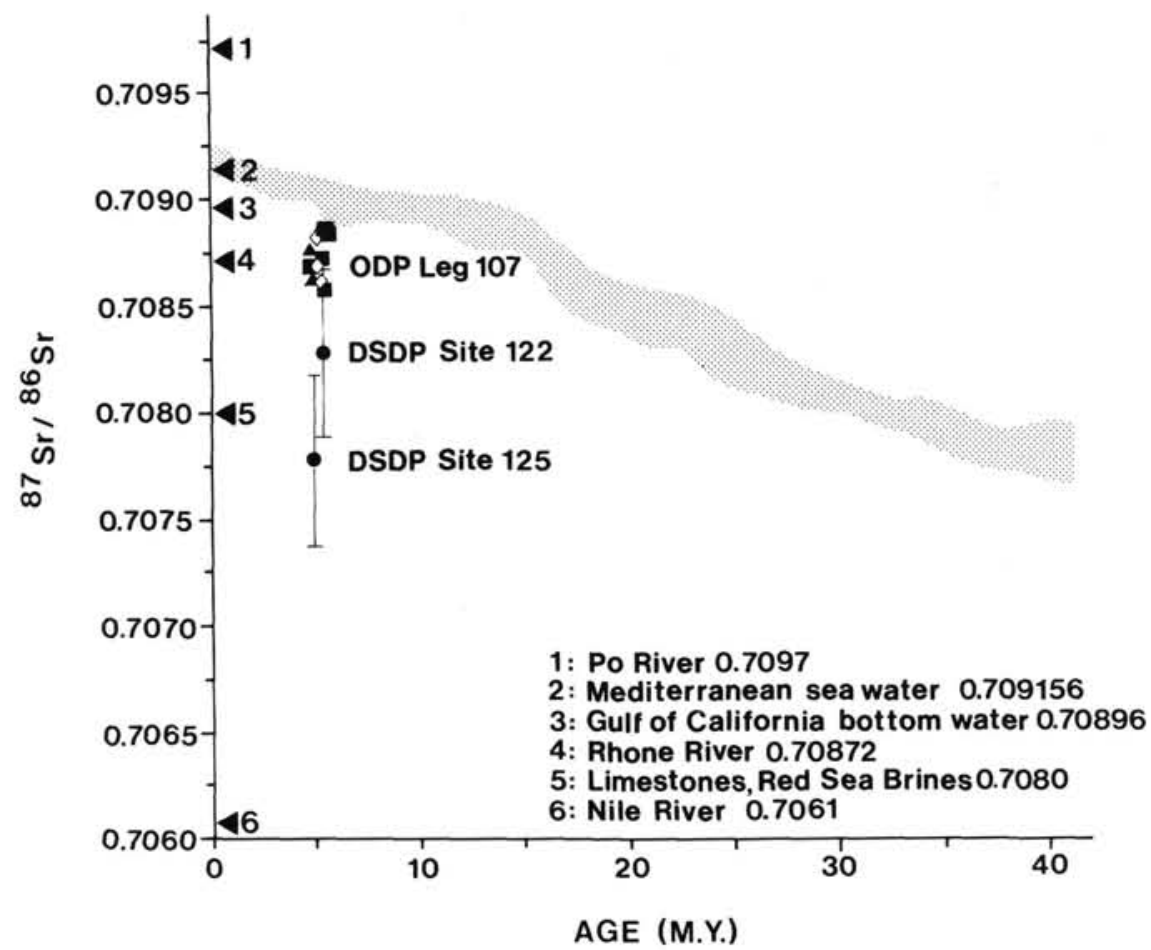

Figure 4. The $\mathrm{Sr}$ isotopic ratios of the ODP Leg 107 evaporites plot below the $\mathrm{Sr}$ seawater curve (dotted area) and have values similar to those of the modern Rhone River discharge (4). This river drains an area with a high abundance of Mesozoic limestones, which have an average value of 0.7080 (Holland, 1984). Two sulfates measured by Clauer (1976) are also plotted. The sulfate from the Balearic Basin (Site 122) occurs within analytical error $\left(4 \times 10^{-4}\right)$ of values for these two rivers which flow into the western Mediterranean Sea. A sulfate from the Ionian Sea (Site 125), central Mediterranean, might have been influenced by the very unradiogenic Nile water (6). All values from the literature were corrected to our SRM $987=0.710235$. The size of the seawater curve and the Leg 107 evaporite symbols include an analytical error of $2 \times$ $10^{-5}$. Seawater values are from Koepnick et al. (1985), DePaolo and Ingram (1985), Hess et al. (1986), and DePaolo (1986).

Table $3 .{ }^{87} \mathrm{Sr} /{ }^{86} \mathrm{Sr}$ ratios of handpicked planktonic foraminifers from sedimentological Unit IV, Hole 654A.

\begin{tabular}{|c|c|c|c|}
\hline Sample & $\begin{array}{l}\text { Depth } \\
\text { (mbsf) }\end{array}$ & ${ }^{87} \mathrm{Sr} /{ }^{86} \mathrm{Sr}$ & $\begin{array}{l}\text { Standard } \\
\text { error }^{\mathrm{a}}\end{array}$ \\
\hline $40 \mathrm{R}-3,91$ & 352.11 & 0.708844 & \pm 14 \\
\hline $41 \mathrm{R}-1,89$ & 358.69 & 0.708864 & \pm 18 \\
\hline $42 \mathrm{R}-1,89$ & 368.29 & 0.708811 & \pm 12 \\
\hline $42 \mathrm{R}-3,89$ & 371.29 & 0.708836 & \pm 12 \\
\hline $43 \mathrm{R}-1,89$ & 377.99 & 0.708862 & \pm 18 \\
\hline \multirow[t]{2}{*}{$45 \mathrm{R}-1,86$} & 397.26 & 0.708959 & \pm 16 \\
\hline & & 0.708944 & \pm 10 \\
\hline $45 \mathrm{R}-3,86$ & 400.26 & 0.708858 & \pm 18 \\
\hline
\end{tabular}

\footnotetext{
a Analytical uncertainty represents 2 standard errors of the mean of 100 to 200 individual measurements and refers to the last two digits of the ratio.
}

gest an age for the dolomitization between 15 and $12 \mathrm{Ma}$. As this event must be younger than about $6 \mathrm{Ma}$, the dolomitizing fluids were not normal seawater.

In summary, the evaporites, as well as the carbonates, from the investigated holes were not formed or chemically reworked in a brine with normal marine, late Miocene ${ }^{87} \mathrm{r} /{ }^{86} \mathrm{Sr}$ values. The high variability of the $\mathrm{Sr}$ isotopic ratios ranging between 0.70886 and 0.70861 suggests large variations in the ${ }^{87} \mathrm{Sr} /{ }^{86} \mathrm{Sr}$ composition of the brines or pore fluids. Such a large variation
Table 4. ${ }^{87} \mathrm{Sr} /{ }^{86} \mathrm{Sr}$ ratios of two dolomitic muds from top of Unit IV, Hole $654 \mathrm{~A}$.

\begin{tabular}{lccc}
\hline Sample & $\begin{array}{c}\text { Depth } \\
\text { (mbsf) }\end{array}$ & ${ }^{87} \mathrm{Sr} /{ }^{86} \mathrm{Sr}$ & $\begin{array}{c}\text { Standard } \\
\text { error }^{\mathrm{a}}\end{array}$ \\
\hline 40R-1, 41 & 348.61 & 0.708868 & \pm 10 \\
$40 \mathrm{R}-1,91$ & 349.11 & 0.708828 & \pm 18
\end{tabular}

a Analytical uncertainty represents 2 standard errors of the mean of 100 to 200 individual measurements and refers to the last two digits of the ratio.

does not occur in sea water over a period of about $1 \mathrm{~m}$.y. Thus, the ${ }^{87} \mathrm{Sr} /{ }^{86} \mathrm{Sr}$ ratios of the evaporites cannot be used to estimate their age, but must be at least partially diagnostic of the fluids from which they formed.

\section{DISCUSSION}

\section{What Processes Could Produce the Observed Lowering of the ${ }^{87} \mathrm{Sr} /{ }^{86} \mathrm{Sr}$ Ratio?}

The Mediterranean Sea is a relatively small sea with substantial continental input and may not have the same $\mathrm{Sr}$ isotope history as the open ocean, although it currently has a Sr isotopic value identical to the open ocean. If we assume that the evaporites obtained their measured strontium isotope ratios during 
Table 5. Calcium carbonate and dolomite content of the nannofossil chalk, Unit IV, Hole 654A.

\begin{tabular}{|c|c|c|c|}
\hline Sample & $\begin{array}{l}\text { Depth } \\
\text { (mbsf) }\end{array}$ & $\underset{(\%)}{\mathrm{CaCO}_{3}}$ & $\underset{(\%)}{\mathrm{CaMg}\left(\mathrm{CO}_{3}\right)_{2}}$ \\
\hline $40 \mathrm{R}-1,41$ & 348.61 & 0 & 50 \\
\hline $40 \mathrm{R}-1,91$ & 349.11 & 0 & 56 \\
\hline $40 \mathrm{R}-1,141$ & 349.61 & 23 & 15 \\
\hline $40 \mathrm{R}-2,41$ & 350.11 & 26 & 20 \\
\hline $40 \mathrm{R}-2,91$ & 350.61 & 33 & 4 \\
\hline $40 \mathrm{R}-2,145$ & 351.15 & 32 & 3 \\
\hline $40 \mathrm{R}-3,41$ & 351.61 & 32 & \\
\hline $40 \mathrm{R}-3,91$ & 352.11 & 38 & 5 \\
\hline $40 \mathrm{R}-4,41$ & 353.11 & 35 & 4 \\
\hline $40 R-4,91$ & 353.61 & 37 & 4 \\
\hline $40 \mathrm{R}-4,141$ & 354.11 & 37 & 4 \\
\hline $40 \mathrm{R}-5,41$ & 354.61 & 31 & \\
\hline $41 R-1,46$ & 358.26 & 25 & 4 \\
\hline $41 \mathrm{R}-1,89$ & 358.69 & 41 & \\
\hline $41 \mathrm{R}-1,141$ & 359.21 & 36 & \\
\hline $41 \mathrm{R}-2,46$ & 359.76 & 39 & \\
\hline $41 \mathrm{R}-2,89$ & 360.19 & 30 & \\
\hline $41 R-2,141$ & 360.71 & 41 & \\
\hline $41 \mathrm{R}-3,46$ & 361.26 & 41 & \\
\hline 41R-3, 89 & 361.69 & 29 & \\
\hline $41 R-4,46$ & 362.76 & 40 & 12 \\
\hline $41 R-4,89$ & 363.19 & 31 & \\
\hline $41 R-4,141$ & 363.71 & 39 & \\
\hline $42 \mathrm{R}-1,41$ & 367.81 & 44 & \\
\hline $42 \mathrm{R}-1,98$ & 368.29 & 42 & \\
\hline $42 \mathrm{R}-1,141$ & 368.81 & 47 & \\
\hline $42 R-2,41$ & 369.31 & 46 & \\
\hline $42 R-2,89$ & 369.79 & 39 & \\
\hline $42 R-2,141$ & 370.31 & 45 & \\
\hline $42 \mathrm{R}-3,41$ & 370.81 & 44 & \\
\hline $42 R-3,89$ & 371.29 & 32 & \\
\hline $42 R-3,141$ & 371.81 & 49 & \\
\hline $42 R-4,41$ & 372.31 & 43 & \\
\hline $42 \mathrm{R}-4,89$ & 372.79 & 37 & \\
\hline $42 \mathrm{R}-4,14 \mathrm{I}$ & 373.31 & 49 & \\
\hline $42 \mathrm{R}-5,41$ & 373.81 & 49 & \\
\hline $42 \mathrm{R}-5,89$ & 374.29 & 49 & \\
\hline $42 \mathrm{R}-5,141$ & 374.81 & 49 & \\
\hline $43 \mathrm{R}-1,41$ & 377.51 & 47 & \\
\hline $43 \mathrm{R}-1,89$ & 377.99 & 44 & \\
\hline $43 \mathrm{R}-1,141$ & 378.51 & 47 & \\
\hline $43 R-2,41$ & 379.01 & 51 & \\
\hline $43 R-2,89$ & 379.49 & 48 & \\
\hline $43 R-2,141$ & 380.01 & 51 & \\
\hline $43 R-3,41$ & 380.51 & 50 & \\
\hline $43 \mathrm{R}-3,89$ & 380.99 & 41 & \\
\hline $43 \mathrm{R}-3,141$ & 381.51 & 52 & \\
\hline $43 R-4,41$ & 382.01 & 57 & \\
\hline $43 R-4,89$ & 382.49 & 49 & \\
\hline $43 R-4,141$ & 383.01 & 50 & \\
\hline $43 R-5,41$ & 383.51 & 57 & \\
\hline $43 R-5,89$ & 383.99 & 45 & \\
\hline $43 R-5,141$ & 384.51 & 52 & \\
\hline $44 \mathrm{R}-1,87$ & 387.67 & 45 & \\
\hline $44 \mathrm{R}-1,141$ & 388.21 & 47 & \\
\hline $44 R-2,87$ & 389.17 & 38 & 6 \\
\hline $44 \mathrm{R}-2,14 \mathrm{l}$ & 389.71 & 29 & 24 \\
\hline $44 \mathrm{R}-3,87$ & 390.67 & 34 & 14 \\
\hline $44 R-4,87$ & 392.17 & 27 & 26 \\
\hline $44 \mathrm{R}-4,141$ & 392.71 & 27 & 21 \\
\hline 44R-5, 87 & 393.67 & 27 & 18 \\
\hline $44 \mathrm{R}-5,141$ & 394.21 & 31 & 22 \\
\hline $44 \mathrm{R}-6,87$ & 395.17 & 37 & 10 \\
\hline $45 \mathrm{R}-1,41$ & 396.81 & 37 & 10 \\
\hline $45 \mathrm{R}-1,86$ & 397.26 & 39 & 9 \\
\hline $45 \mathrm{R}-1,141$ & 397.81 & 36 & 11 \\
\hline $45 R-2,41$ & 398.31 & 40 & 10 \\
\hline $45 R-2,86$ & 398.76 & 40 & 8 \\
\hline $45 R-2,141$ & 399.31 & 36 & 7 \\
\hline $45 \mathrm{R}-3,41$ & 399.81 & 38 & 6 \\
\hline $45 R-3,86$ & 400.26 & 42 & 5 \\
\hline $45 \mathrm{R}-3,141$ & 400.81 & 43 & 3 \\
\hline $45 \mathrm{R}-4,41$ & 401.31 & 34 & 4 \\
\hline $45 R-4,86$ & 401.76 & 42 & 4 \\
\hline $45 \mathrm{R}-4,141$ & 402.31 & 39 & 4 \\
\hline $45 \mathrm{R}-5,41$ & 402.81 & 36 & \\
\hline $45 R-5,86$ & 403.26 & 33 & \\
\hline $45 \mathrm{R}-5,135$ & 403.75 & 35 & \\
\hline
\end{tabular}

their precipitation, the low ratios could have been produced by the following processes.

The dilution of marine water by run-off can only have a major influence on the ${ }^{87} \mathrm{Sr} /{ }^{86} \mathrm{Sr}$ ratio of marine water if the basin has a restricted communication with the open ocean. The more extreme the ${ }^{87} \mathrm{Sr} /{ }^{86} \mathrm{Sr}$ ratio of the continental input, the higher the potential influence in a restricted marine basin. This is confirmed by $\mathrm{Sr}$ isotopic measurements on living shells of Hudson Bay. The shells incorporate an Atlantic ${ }^{87} \mathrm{Sr} /{ }^{86} \mathrm{Sr}$ ratio even when the water had a salinity of only $16 \%$ ( $50 \%$ river water; Faure et al., 1967). A restriction or even total isolation of a basin is usually necessary because the $\mathrm{Sr}$-concentration ratio of continental water to seawater is nominally $1: 10$. In the modern Mediterranean Sea, some of the large rivers have low ${ }^{87} \mathrm{Sr} /{ }^{86} \mathrm{Sr}$ ratios, resulting from the abundance of mafic rocks and Mesozoic limestones in their drainage areas. For example, the Nile has a value of 0.7060 , and the Rhone 0.70872 (Brass, 1976; Albarède and Michard, 1987) (Fig. 4). Such water is a likely source for water with low Sr-isotopic ratios in the Miocene as well.

Formation of anomalous bottom water by mixing with brines with low ${ }^{87} \mathrm{Sr} /{ }^{86} \mathrm{Sr}$ ratios could have been another process contributing to the low $\mathrm{Sr}$-isotopic ratios in the evaporites. Modern basins where the bottom water contains lower ${ }^{87} \mathrm{Sr} /{ }^{86} \mathrm{Sr}$ ratios than the contemporaneous open seawater $(0.709155)$ are the Gulf of California $\left(24 \times 10^{-5}\right.$ below seawater; Tarnoff and Hurst, 1985), and the Red Sea $\left(12 \times 10^{-3}\right.$ below seawater; Faure and Jones, 1969). Both basins are characterized by active spreading centers. The hydrothermal alteration of the basaltic basement and the weak mixing of the water column produces a bottom-water layer with a low $\mathrm{Sr}$ isotopic composition. Also, the dissolution of older evaporites can be a source for aberrant bottom water brines, as is the case in the Valdivia and the Suakin deep brines of the Red Sea (Zierenberg and Shanks, 1986). Evaporites formed in such aberrant bottom water would be expected to have a lower $\mathrm{Sr}$ isotopic ratio than normal seawater. Although the southeastern Tyrrhenian Sea had active basalt volcanism during the late Miocene (DSDP Site 373; Hsü, Montadert, et al., 1978), evaporite deposition took place in the northwestern portion of the basin. Interaction between basalt and overlying Pliocene sediment in the southeast occurred at low temperature (Kastens, Mascle, et al., 1987: Hole 651) in accordance with low heatflow, clearly lower than in the Guaymas Basin of the Gulf of California (Gieskes et al., 1986). In addition, the sedimentary structures and the dwarfed marine fauna in the Tyrrhenian Sea drillcores suggest that it was not a deep basin and favor the interpretation of shallow water evaporite deposition within a restricted marine to lacustrine environment. Furthermore, the volume of the Messinian evaporites is larger than any known to form in any recent deep basin (Hsü, 1972). Based on these arguments, we assume that basalts were not the source for $\mathrm{Sr}$ with low isotopic ratios in the interstitial water of the Miocene sediments. Also, an aberrant (low ratio) bottom water layer caused by hot brines is unlikely.

Alteration during burial diagenesis by interstitial water with isotopic composition different from contemporaneous seawater could be another explanation for the low Sr-isotopic ratios in the evaporites. Most pore water profiles are characterized by a nearly linear increase in the deviation of the ${ }^{87} \mathrm{Sr} /{ }^{86} \mathrm{Sr}$ ratio (low Sr-isotopic ratios) compared to contemporaneous seawater (Elderfield and Gieskes, 1982). A late diagenesis of the sediments in Holes 652,653 , and 654 can only have affected the late Miocene sediments because the marine fossils of the overlying Pliocene show no deviation from contemporaneous seawater (McKenzie et al., this volume). An unconformity separating the Miocene from the Pliocene is only obvious in Holes 653 and 654. A late overprint of the ${ }^{87} \mathrm{Sr} /{ }^{86} \mathrm{Sr}$ ratios of the evaporites by pore water is unlikely because solution-reprecipitation decreases rapidly with 
depth (Richter and DePaolo, 1987). No upward diffusion/migration of dissolved solids (calcium, magnesium, chloride) due to dissolution of evaporites at depth was detected between the evaporites and the overlying marine sediments in Hole 654A (Kastens, Mascle, et al., 1987). This could perhaps have resulted from the presence of early, lithified gypsum layers. Because no basalts underlie Sites 652, 653, and 654, the influence on the interstitial water by hydrothermal alteration of basalts is unlikely.

Dissolution of older carbonates can also change the pore water composition (Gieskes et al., 1986). In this case, the ${ }^{87} \mathrm{Sr} /{ }^{86} \mathrm{Sr}$ deviation is not as large as when alteration of volcanic material takes place, but the amount of dissolved $\mathrm{Sr}$ is clearly higher (Elderfield and Gieskes, 1982). This possibility can also be excluded because the ${ }^{87} \mathrm{Sr} /{ }^{86} \mathrm{Sr}$ ratio of carbonates is not low enough to significantly change the $\mathrm{Sr}$ isotopic ratio of the pore water and the solution-reprecipitation decreases rapidly with depth (Richter and DePaolo, 1987). The age of the older carbonates underlying the evaporites is not known in the Tyrrhenian Basin.

The only way that volcanic material could have affected the isotopic composition of interstitial waters would be by equilibration with volcanic ash. A volcanic glass layer and volcanic tuff-rich dolomitic mudstone were found in Cores 654A-39R and $-38 \mathrm{R}$, as well as in the evaporitic sequence (Cores 654A$31 \mathrm{R})$. Once again, however, the quantities of $\mathrm{Sr}$ are low and the ratios unknown.

\section{What Processes Could Produce the Low ${ }^{87} \mathrm{Sr} /{ }^{86} \mathrm{Sr}$ Ratios of the Foraminifers and Dolomites in Hole 654A?}

The Tortonian and early Messinian planktonic foraminifers of Hole $654 \mathrm{~A}$ have, with one exception, lower ${ }^{87} \mathrm{Sr} /{ }^{86} \mathrm{Sr}$ ratios than those of late Miocene seawater (DePaolo and Ingram, 1985; Hess et al., 1986; McKenzie et al., 1988; Hodell et al., 1989; Fig. 3). The presence of two distinct dolomitic horizons in Unit IV and of dolomitic clay and siltstone in Unit III in Hole 654 suggests two interpretations for the ${ }^{87} \mathrm{Sr} /{ }^{86} \mathrm{Sr}$ ratios of the foraminifers. Firstly, the surface water in the late Tortonian/early Messinian showed an increasing influence of freshwater with low $\mathrm{Sr}$ isotopic ratio due to the onset of restricted circulation, and/or secondly, the sediments and, therefore, the fossils of this unit were diagenetically altered. The first possibility is the least likely because the sediments and fauna of Unit IV indicate a transgressive environment in the Tortonian. The strong bioturbation speaks for a well oxygenated bottom water, which is only possible in a well mixed water column. Thus, we have to consider post-depositional diagenesis. The strong increase in the dolomite content of the sediments in Core 654A-40R-1 (Fig. 3) is continued in Unit III, Core 654A-39R. In the same interval, bioturbation decreases, the sediments are increasingly laminated, and a petroliferous smell characterizes the sediments of Cores $654 \mathrm{~A}-41 \mathrm{R}$ and $-40 \mathrm{R}$. The highest organic carbon content $(2.4 \%)$ was measured in Core 654A-39R-1. A relatively high abundance of pyrite was noted from Core 654A-43R upward. Siliceous biogenic components, fish remains, and the high organic content in the finely laminated sediments of Unit III from 312.6 to 348.9 mbsf (Cores 654A-36R-1, $110 \mathrm{~cm}$, to $654 \mathrm{~A}-40 \mathrm{R}-1,7.5 \mathrm{~cm}$ ) point to an open marine environment with a high surface water productivity and anoxic bottom water conditions. In general, the pore water concentrations of $\mathrm{Ca}^{2+}, \mathrm{Mg}^{2+}$, and $\mathrm{SO}_{4}^{2-}$ are higher in Messinian and Tortonian sediments than in the younger, overlying strata. An increase in alkalinity and a pronounced magnesium and sulfate depletion in pore water Sample 654A-40R-3, $140-150 \mathrm{~cm}$ ( $352.6 \mathrm{mbsf})$ coincides with the abrupt increase in dolomite abundance at the top of Unit IV. Therefore, we interpret the dolomitization of the nannofossil chalk in Unit IV as an early dolomitization in the sulfate reduction zone. Seawater diffuses into the sediment and provides the magnesium ions required for the development of the dolomitic horizons (Baker and Burns, 1985; Compton and Siever, 1986). This interpretation is supported by the relatively high sedimentation rate for Unit IV of $78 \mathrm{~m} / \mathrm{Ma}$ and the measured $\mathrm{Sr}$ content of $250 \mathrm{ppm}$ of our two dolomite samples. This concentration suggests primary, early precipitation within the sediment from a pore water with a marine $\mathrm{Sr} / \mathrm{Ca}$ ratio (Baker and Burns, 1985). The high $\mathrm{Ca}^{2+}$ content in the interstitial water of late Miocene sediments, up to $\sim 240 \mathrm{mbsf}$, might be due to a stoichiometric replacement of calcite or aragonite by dolomite (Morrow, 1982). We assume that this diagenesis occurred during the early Messinian with the beginning of the deposition of the "Tripoli-like" sediments. But, the marine $\mathrm{Sr} / \mathrm{Ca}$ ratio does not imply that the $\mathrm{Sr}$ is entirely marine. Volcanic ash present in dolomicrites of Unit III (Core 654A-38R) may have reacted with advecting porewater yielding a less radiogenic solution. A minor additional source might also be the chemical alteration of clays and other detrital minerals. The pore water with the low ${ }^{87} \mathrm{Sr} /{ }^{86} \mathrm{Sr}$ ratio also precipitated overgrowths on the foraminifers. The very small variation in the stable isotopic results of some planktonic foraminifers (Table 6) might support the diagenetic overprint by a marine-derived interstitial water. The presence of one marine foraminifer sample in one of the lowermost samples can be explained by a selective diagenesis of interstitial water.

\section{What Process Could Have Produced the Low Sr Isotopic Ratios of the Evaporites?}

The data of Hole $654 \mathrm{~A}$ will be discussed first because the recovered sediments and our measurements provide the most complete record of the Upper Evaporites in the Tyrrhenian Sea and the evaporites display the widest range of ${ }^{87} \mathrm{Sr} /{ }^{86} \mathrm{Sr}$ ratios. The lowermost two samples have an average ratio of 0.70885 , which is essentially the same as ratios obtained for the foraminifers and the dolomites of Unit IV. The ratios are also relatively close to the value for contemporaneous seawater (Fig. 3). The balatino-gypsum of gypsum-rich interval 5 (311 mbsf) is finely laminated and has a dark grey color. This coloration might be due to an elevated content of organic matter. The sample from gypsum-poor interval 4 (300 mbsf) is secondary gypsum in gypsiferous and calcareous mudstone. Pyrite is abundant in this interval. Based on these facts, we interpret the deposition of the first balatino-layer to have occurred in an environment similar to that in which the dolomitization of Unit III and IV occurred, probably a restricted marine environment with anoxic bottom water and a poorly mixed water column. The low ${ }^{87} \mathrm{Sr} /{ }^{86} \mathrm{Sr}$ ratio of this interval can be due to a high influence of freshwater and/or to $\mathrm{Sr}$ released by alteration of volcanic material. Then, with a color change in the balatino-gypsum from dark grey to light yellowish and white (less organic material) in interval 4, a decrease from an average $\mathrm{Sr}$ ratio of 0.70886 to 0.70873 is observed. It is interesting that the intervals having less gypsum have the lowest $\mathrm{Sr}$ isotope ratios. We interpret this as a consequence of the early lithification of the balatino-layers in the gypsum-rich intervals, which retained the more "marine" brine

Table 6. Stable isotopic results of planktonic foraminifers from lithologic Unit IV, Hole 654A.

\begin{tabular}{cccc}
\hline Sample & $\begin{array}{c}\text { Depth } \\
\text { (mbsf) }\end{array}$ & $\begin{array}{c}\delta^{13} \mathrm{C} \\
(\% \circ \mathrm{PDB})\end{array}$ & $\begin{array}{c}\delta^{18} \mathrm{O} \\
(\% \circ \mathrm{PDB})\end{array}$ \\
\hline 40R-5, 71 & 354.91 & 1.73 & -0.83 \\
42R-2, 11 & 369.01 & 1.79 & -0.15 \\
43R-1, 11 & 377.21 & 1.16 & -0.43 \\
43R-3, 89 & 380.99 & 1.45 & -0.95 \\
44R-1, 89 & 387.69 & 1.16 & -0.86 \\
45R-3,86 & 400.26 & 1.12 & -0.27 \\
\hline
\end{tabular}


values. Conversely, the gypsum-poor, more porous intervals interacted after their deposition during erosional events with continental waters to a greater extent, which resulted in more extensive dissolution and reprecipitation of gypsum. Most of the samples from the gypsum-poor intervals are recrystallized selenites (Table 1). We interpret this decrease in the $\mathrm{Sr}$ ratios to be associated with a sea level drop in the Tyrrhenian Basin. This could have occurred either by an isolation of the Tyrrhenian Basin from the western Mediterranean Sea, or more probably, by a general sea level drop in the Mediterranean Sea during the onset of restricted circulation and intermittent isolation of the Mediterranean Sea from the Atlantic Ocean. The isolation and the subsequent evaporation limited the amount of marine-derived $\mathrm{Sr}$ and allowed increasing dilution by freshwater with a low ${ }^{87} \mathrm{Sr} /{ }^{86} \mathrm{Sr}$ ratio. The drop of sea level also allowed groundwater movement into the porous gypsum-poor muds, sands, and silts. Sporadic seawater inflow from the Atlantic ocean through the Betic Strait (Müller and Hsü, 1987) and the Rif Strait brought marine fauna into the basins of the drawndown Mediterranean Sea and provided the dissolved salts required for evaporite formation. The marine influence was not significant enough to increase the $\mathrm{Sr}$ isotopic composition of the brine. A similar decrease in $\mathrm{Sr}$ isotopic ratios to 0.70765 in Messinian carbonates from Hole 132 has been documented by Clauer (1976). On the other hand, the early Messinian and early Pliocene samples are, within analytical error, similar or slightly higher than seawater. In addition, the late Messinian carbonate falls clearly below contemporaneous seawater values and the samples from Leg 107. This supports the interpretation that the evaporite values represent the mixed brine, whereas the carbonate with the lowest $\mathrm{Sr}$ ratio (Clauer, 1976) seems to be only influenced by freshwater.

A similar interpretation can be applied to Hole 653B where a secondary gypsum vein has a ${ }^{87} \mathrm{Sr} /{ }^{86} \mathrm{Sr}$ value $(0.70883)$ close to the seawater curve (0.70892). This might represent a stage of the upper evaporitic phase during which marine water had a greater influence on the brine composition. This water could move into the calcareous, gypsiferous mud and influence recrystallization of the gypsum. The nodular and laminated gypsum samples from this hole were formed in a similar environment to that for the upper part of Hole $654 \mathrm{~A}$.

Continuous sedimentation across the Miocene/Pliocene boundary occurred in Hole 652, where all lacustrine Messinian sediments were deposited during the lowermost reversed polarity interval of Gilbert (Channell et al., this volume). A direct correlation of the lacustrine sequence with the Upper Evaporites of Holes $653 \mathrm{~B}$ and $654 \mathrm{~A}$ is not possible. Also, a correlation of the lacustrine sediments in Hole 652 with the final "Lago Mare" stage of the eastern Mediterranean (Ruggieri, 1967) cannot be made due to lack of diagnostic fossils (see Cita et al., this volume). The depositional environment of Hole 652A might have been similar to the Dead Sea (Neev and Emery, 1967) with a relatively steady water body. Though variable, the $\mathrm{Sr}$ ratios are in the range of the other two holes, and exhibit a clear up-hole increase. This could indicate that the uppermost anhydrites were precipitated from a brine that was progressively influenced by marine water which initiated the final filling of the Mediterranean Sea in the early Pliocene.

The suggestion that a drop in sea level lead to increased influence of continental water on the brine composition in the Tyrrhenian Sea is supported by the following:

1. The influence of freshwater on gypsum recrystallization has been confirmed several times by previous stable isotopic studies of gypsum and carbonate samples from the upper evaporites in the Mediterranean Sea (Fontes et al., 1973a, b; Pierre, 1974; Pierre and Fontes, 1978).

2. Sedimentary features of current activity such as reworking of gypsum (rip-up clasts), algal structures in the gypsum lay- ers, and possibly mud-cracks (Kastens, Mascle et al., 1987: Hole 654) favor shallow water deposition with subaerial exposure from time to time.

3. The channel of Corsica is a large and deep river system which eroded Messinian sediments during uppermost Messinian time in the southern Corsica basin (Aleria, 1980). Therefore, saline lakes could have existed in the relatively deep Tyrrhenian Sea hundreds of meters below Atlantic sea level. These lakes occasionally reached saturation as suggested by halite molds observed in Hole 652A (Kastens, Mascle, et al., 1987). The Tyrrhenian Sea probably never was completely evaporated in the late Messinian because a steady river water inflow from the surrounding land areas (Italy, Corsica, Sardinia) replenished the water body and a smaller surface area lead to decreasing rates of evaporation (Debenedetti, 1982). This environment has many similarities with the modern Dead Sea (Neev and Emery, 1967).

4. A greater influence of continent-derived brines was noted toward the eastern Mediterranean based on ions coprecipitated with the evaporites (Kushnir, 1982).

5. Fluctuations in the water composition and source are also observed in Cores $654 \mathrm{~A}-29 \mathrm{R}$ to $-27 \mathrm{R}$ with the occurrence of nannofossils and assemblages of Ammonia beccarii tepida and Cyprideis, the latter living in shallow brackish water.

6. Fluctuations in the discharge of rivers can significantly change the ${ }^{87} \mathrm{Sr} /{ }^{86} \mathrm{Sr}$ ratio of that discharge $\left(30 \times 10^{-4}\right)$ (Eastin and Faure, 1970) and could easily have had an influence in a shallow isolated basin.

7. The rivers in the western Mediterranean today have a lower ${ }^{87} \mathrm{Sr} /{ }^{86} \mathrm{Sr}$ ratio than seawater (Brass, 1976; Albarède and Michard, 1987). This ratio is in the range of the measured gypsum samples (Fig. 4).

Although it is not possible to make exact mass balance calculations with the results obtained because of a lack of data for other Mediterranean basins, it is important to evaluate whether the ${ }^{87} \mathrm{Sr} /{ }^{86} \mathrm{Sr}$ composition of the western Mediterranean could have been changed in a reasonable time by the influx of fresh waters. Because the ${ }^{87} \mathrm{Sr} /{ }^{86} \mathrm{Sr}$ composition of the rivers are significantly different for the western and eastern Mediterranean, two estimates must be made: first, only for the western Mediterranean and second for the entire Mediterranean Sea. For the western Mediterranean Sea, we use the Rhone River values because the Rhone is the dominant fresh water source. In order to change the strontium-isotopic ratio of a Mediterranean evaporite $(0.70884)$ by one half of the difference between the ratio of the fresh water inflow (Rhone: 0.70872; Albarède and Michard, $1987)$ and the contemporaneous marine value $(0.70897)$, it is necessary to contribute a mass of $\mathrm{Sr}$ equal to the mass of $\mathrm{Sr}$ in the western Mediterranean water present at the time of isolation from the marine source ( $50 \%$ dilution). We conservatively assume that the isolation was instantaneous and that no further marine input occurred until the $\mathrm{Sr}$-isotope ratio was altered by the required amount. The maximum volume of the western Mediterranean Sea was approximately $1424 \times 10^{3} \mathrm{~km}^{3}(854.6$ $\times 10^{3} \mathrm{~km}^{2}$ surface $\times 1.67 \mathrm{~km}$ deep; Emelyanov and Shimkus, 1986). The $\mathrm{Sr}$ concentration in seawater is $8000 \mu \mathrm{g} / \mathrm{L}$ and, thus, the western Mediterranean contains $1.1392 \times 10^{16} \mathrm{~g}$ of Sr. For the Rhone, Ebro, and Tiber a mean Sr concentration of 500 $\mu \mathrm{g} / \mathrm{L}$ is assumed (Albarède and Michard, 1987) and the annual discharge of these rivers is $2525 \mathrm{~m}^{3} / \mathrm{s}$ (Emelyanov and Shimkus, 1986). These data imply that it would have taken $1.1392 \times 10^{16}$ $\mathrm{g} / 3.98142 \times 10^{10} \mathrm{~g} \mathrm{yr}^{-1}$ or $2.861 \times 10^{5}$ yrs to reach a ${ }^{87} \mathrm{Sr} /{ }^{86} \mathrm{Sr}$ of 0.708842 in the western Mediterranean. Consideration of the entire Mediterranean Sea significantly alters the numbers because of the low ${ }^{87} \mathrm{Sr} /{ }^{86} \mathrm{Sr}(0.7060)$ and the relative high $\mathrm{Sr}$ concentration (234 $\mu \mathrm{g} / \mathrm{L}$; Brass, 1976) of the Nile River. Prior to impoundment by the Aswan dam, this river alone transported at least $1.92 \times 10^{10} \mathrm{~g} \mathrm{Sr} / \mathrm{yr}\left(2600 \mathrm{~m}^{3} / \mathrm{sec} \times 234 \mu \mathrm{g} / \mathrm{L}\right)$ into the 
Mediterranean Sea. For the remaining discharge, we use a mean of $500 \mu \mathrm{g} / \mathrm{L}$ and $2525 \mathrm{~m}^{3} / \mathrm{sec}\left(3.98142 \times 10^{10} \mathrm{~g} \mathrm{Sr} / \mathrm{yr}\right)$. Calculations with a ${ }^{87} \mathrm{Sr} /{ }^{86} \mathrm{Sr}$ ratio of 0.70646 (the total of Rhone = $0.70872 \times 0.67$, and Nile $=0.7060 \times 0.33 ;$ numbers from Brass, 1976; Albarède and Michard, 1987) give a dilution of the Mediterranean seawater by $11.2 \%$. In this expanded scenario it would take $3.3895 \times 10^{15} \mathrm{~g} / 5.9 \times 10^{10} \mathrm{~g} \mathrm{yr}^{-1}$ or $57,450 \mathrm{yr}$ to reach a ${ }^{87} \mathrm{Sr} /{ }^{86} \mathrm{Sr}$ ratio of 0.70884 . The ${ }^{87} \mathrm{Sr} /{ }^{86} \mathrm{Sr}$ average of all measured evaporites $(0.70872)$ requires a dilution of the Mediterranean seawater by $21.8 \%$, which is reached after $112,325 \mathrm{yr}$. We are aware of the many assumptions and unknown variables in this simple calculations, but the implications are either the Mediterranean Sea was isolated for a much longer time than previously assumed, or the Mediterranean Sea was much shallower at the time of isolation, or there is some other major unidentified source of $\mathrm{Sr}$ to the Mediterranean during the Miocene, or rapid variations of climatic conditions caused large fluctuations in the ${ }^{87} \mathrm{Sr} /{ }^{86} \mathrm{Sr}$ composition of the rivers (e.g., increased weathering of late Jurassic limestones during the Messinian), and/or diagenetic effects in the evaporites are larger than assumed.

The comparison of the ${ }^{87} \mathrm{Sr} /{ }^{86} \mathrm{Sr}$ ratios found in sulfates from the Tyrrhenian Sea with those from Hole 122 (Balearic Basin) and Hole 125 (Ionian Sea) (Clauer, 1976) suggest that the evaporites from different basins in the Mediterranean Sea may have had distinct ${ }^{87} \mathrm{Sr} /{ }^{86} \mathrm{Sr}$ compositions (Fig. 4). Hole 122 has a value similar to those from Leg 107, whereas Hole 125, farther to the east and away from the marine source, appears to have had a greater riverwater influence as suggested by the previous calculations (e.g., the Nile, ${ }^{87} \mathrm{Sr} /{ }^{86} \mathrm{Sr}=0.7060 ; \times 4.7$ higher $\mathrm{Sr}$ concentration than Rhone). In case of an isolation of the eastern Mediterranean Sea from the western part, ${ }^{87} \mathrm{Sr} /{ }^{86} \mathrm{Sr}$ ratios in the former basin would be expected to rise, and to fall in the latter basin. Ongoing measurements of Messinian evaporites from the eastern Mediterranean Sea might suggest several such events. The Tyrrhenian Sea was not a unique feature during Messinian time, but was actually one of several shallow water basins in the deep western Mediterranean. Studies of ionic concentrations and stable isotope ratios in the gypsum and "Lago Mare" sediments suggest similar conclusions to those stated above (Fontes et al., 1973a, b; Pierre and Fontes, 1978; Ricchiuto and McKenzie, 1978; Kushnir, 1982).

\section{CONCLUSIONS}

The data strongly suggest that it is not possible to utilize the ${ }^{87} \mathrm{Sr} /{ }^{86} \mathrm{Sr}$ ratios of the Upper Evaporites of the Tyrrhenian Sea for stratigraphic correlation due to the influence of continental waters in a restricted basin and/or diagenesis. Care must be exercised in applying this method for dating ancient evaporite deposits, even if marine fossils are present. Applying ${ }^{87} \mathrm{Sr} /{ }^{86} \mathrm{Sr}$ ratios as a geochemical tracer, we are able to identify two depositional environments in the late Messinian. The onset of evaporite formation occurred in a restricted marine basin, probably with anoxic bottom conditions as suggested by finely laminated darkly colored evaporites. Their ${ }^{87} \mathrm{Sr} /{ }^{86} \mathrm{Sr}$ ratios are slightly lower than contemporaneous seawater, but are similar to early marine, diagenetically altered foraminifers and dolomites of the late Tortonian/early Messinian. A decrease in the ${ }^{87} \mathrm{Sr} /{ }^{86} \mathrm{Sr}$ ratio, accompanied by a color change in the balatino-gypsum, is interpreted as the product of increasing freshwater influence due to a drastic drop in sea level. Fresh water with low $\mathrm{Sr}$ isotopic ratios mixed with the marine brines and thus influenced the $\mathrm{Sr}$ isotopic composition of gypsum during formation and early chemical reworking. Sporadic marine incursions from the Atlantic introduced the marine fauna. The lacustrine sediments from Hole $652 \mathrm{~A}$, possibly later than the Upper Evaporites, were deposited in an environment similar to the modern Dead Sea. The steadily increasing ${ }^{87} \mathrm{Sr} /{ }^{86} \mathrm{Sr}$ values of the lacustrine anhydrites as the Miocene/Pliocene boundary is approached suggest that the influence of marine water into the Mediterranean Sea increased, leading to the final filling of the Mediterranean Sea in the early Pliocene. This event terminated the unique hydrologic conditions that produced the saline lakes at the bottom of the Tyrrhenian Basin near the end of the Messinian salinity crisis.

\section{ACKNOWLEDGMENTS}

Reviews by Kim Kastens and Floyd McCoy, and by several anonymous reviewers helped to improve this manuscript. Discussions with Dave Hodell, Charlotte Schreiber, Susan Hovorka, and Robert Koepnick brought new ideas to the project. We are grateful for assistance in the laboratory by Bob Schuster and Ann Hetherington. Part of this research was funded by USSAC grant no. 86032118 to J.A.M. We thank ODP for the samples and the opportunity to participate in this Leg by one of us (J.A.M.). This work was done during the tenure of D.W.M. at the University of Florida, made possible by a "Nachwuchsstipendium" of the Swiss National Science Foundation.

\section{REFERENCES}

Aharon, P., Socki, R. A., and Chan, L., 1987. Dolomitization of atolls by seawater convection flow: test of a hypothesis at Niue, South Pacific. J. Geol., 95:187-203.

Albarède, F., and Michard, A., 1987. Evidence for slowly changing ${ }^{87} \mathrm{Sr} /{ }^{86} \mathrm{Sr}$ in runoff from freshwater limestones of southern France. Chem. Geol., 64:55-65.

Aleria, 1980. Le canal de Corse et les bassins nord-tyrrhèniens au Miocène supèrieur et terminal (Messinien); leur èvolution plio-quaternaire. Geol, Medirerr., 7:5-12.

Baker, P. A., and Burns, S. J., 1985. Occurrence and formation of dolomite in organic-rich continental margin sediments. AAPG Bull., 69: 1917-1930.

Brass, G. W., 1976. The variation of the marine ${ }^{87} \mathrm{Sr} /{ }^{86} \mathrm{Sr}$ ratio during Phanerozoic time: interpretation using a flux model. Geochim. Cosmochim. acta, 40:721-730.

Broecker, W. S., Gerard, R. D., Ewing, M., and Heezen, B. C., 1961. In Sears, M. (Ed.) Oceanography, AAAS Publ. 67, American Association for the Advancement of Science, Washington, p. 301.

Broecker, W. S., and Peng, T. H., 1982. Tracers in the Sea. New York (Eldigio).

Burke, W. H., Denison, R. E, Hetherington, E. A., Koepnick, R. B., Nelson, H. F., and Otto, J. B., 1982. Variation of seawater $87 / 86$ throughout Phanerozoic time. Geology, 10:516-519.

Butler, G. P., 1973. Strontium geochemistry of modern and ancient calcium sulphate minerals. In Purser, B.H. (Ed.), The Persian-Gulf: Berlin (Springer), 423-542.

Clauer, N., 1976. ${ }^{87} \mathrm{Sr} /{ }^{86} \mathrm{Sr}$ composition of evaporitic carbonates and sulphates from Miocene sediment cores in the Mediterranean Sea (DSDP, Leg 13). Sedimentology, 23:133-140.

Collerson, K. D., Ullman, W J., and Torgersen, T., 1988. Ground waters with unradiogenic ${ }^{87} \mathrm{Sr} /{ }^{86} \mathrm{Sr}$ ratios in the great artesian basin, Australia. Geology, 16:59-63.

Compton, J. S., and Siever, R., 1986. Diffusion and mass balance of $\mathrm{Mg}$ during early dolomite formation, Monterey Formation. Geochim. Cosmochim. Acta, 50:125-135.

DePaolo, D. J., 1986. Detailed record of the Neogene Sr isotopic evolution of seawater from DSDP Site 590B. Geology, 14:103-106.

De Paolo, D. J., and Ingram, B. L., 1985. High-resolution stratigraphy with strontium isotopes. Science, 227:938-941.

Debenedetti, A., 1982. The problem of the origin of the salt deposits in the Mediterranean and of their relations to the other salt occurrences in the Neogene formations of the contiguous regions. Mar. Geol., 49:91-114.

Eastin, R., and Faure, G., 1970. Seasonal variation of the solute content and the ${ }^{87} \mathrm{Sr} /{ }^{86} \mathrm{Sr}$ ratio of the Olentangy and Scioto rivers at Columbus, Ohio. Ohio J. Sci., 70:170-179.

Elderfield, H., 1986. Strontium isotope stratigraphy. Paleoceanogr, $\mathrm{Pa}$ leoclimatol, Paleoecol., 57:71-90.

Elderfield, H., and Gieskes, J. M., 1982. Sr isotopes in interstitial waters of marine sediments from Deep Sea Drilling Project cores. $\mathrm{Na}$ ture, 300:493-497. 
Emelyanov, E. M., and Shimkus, K. M., 1986. Geochemistry and sedimentology of the Mediterranean Sea. Sedimentology and Petroleum Geology, Dordrecht, Holland (D. Reidel), 553.

Faure, G., and Jones, L. M., 1969. Anomalous strontium in the Red Sea brines. In Degens, E. T., and Ross, D. W. (Eds.) Hot brines and recent heavy metal deposits in the Red Sea, Berlin (Springer), 243250

Faure, G., Hurley, P. M., and Powell, J. L., 1965. The isotopic composition of strontium in surface water from the North Atlantic Ocean. Geochim. Cosmochim. Acta, 29:209-220.

Ferguson, J., Burne, R. V., and Chambers, L. A., 1983. Iron mineralization of peritidal carbonate sediments by continental groundwater, Fisherman Bay, South Australia. Sed. Geol., 34:41-57.

Fontes, J. C., Letolle, R., Nesteroff, W. D., and Ryan, W.B.F., 1973a. Oxygen, carbon, sulfur and hydrogen stable isotopes in carbonate and sulfate mineral phases of Neogene evaporites, sediments and in interstitial waters. In Ryan, W.B.F., Hsü, K. J., et al., Init. Repts. DSDP, 13: Washington (U.S. Govt. Printing Office), 788-796.

Fontes, J. C., Leprivier, C., Melieres, F., and Pierre, C., 1973b. Isotopes stables dans les carbonates èvaporitiques du Miocène supèrieur de la Mèditerranèe occidentale. In Drooger, C. W. (Ed), Messinian events in the Mediterranean. Amsterdam (North Holland), 91100.

Gieskes, J. M., Elderfield, H., and Palmer, M. R., 1986. Strontium and its isotopic composition in interstitial waters of marine carbonate sediments. Earth Planet. Sci. Lett., 77:229-235.

Herrmann, A. G., and Knake, D., 1973. Coulometrisches Verfahren zur Bestimmung von Gesamt-, Carbonat- und Nichtcarbonat- Kohlenstoff in magmatischen, metamorphen und sedimentären Gesteinen. Z. Anal. Chem., 266:196-201.

Hess, J., Bender, M. L., and Schilling, J. G., 1986. Seawater ${ }^{87} \mathrm{Sr} /{ }^{86} \mathrm{Sr}$ evolution from Cretaceous to Present-Applications to Paleoceanography. Science, 231:979-984.

Hodell, D. A., Mueller, P. A., McKenzie, J. A., and Mead, G. A., 1989. Strontium isotope stratigraphy and geochemistry of the late Neogene ocean. Earth Planet. Sci. Lett., 92:165-178.

Holland, H. D., 1984. The chemical evolution of the atmosphere and oceans. Princeton (Princeton Univ.), 582.

Hovorka, S., 1987. Depositional environments of marine-dominated bedded halite, Permian San Andres Formation, Texas. Sedimentology, 34:1029-1054.

Hsü, K. J., 1972. Origin of saline giants: A critical review after the discovery of the Mediterranean evaporite. Earth, Sci. Rev., 8:371-396.

Hsü, K. J., Cita, M. B., and Ryan, W.B.F., 1973. The origin of the Mediterranean evaporites. In Ryan, W.B.F., Hsü, K. J., et al., Init. Repts. DSDP, 13: Washington (U.S. Govt. Printing Office), 12031231.

Hsü, K. J., Montadert, L., et al., 1978. Init. Repts. DSDP, 42, Pt. 1: Washington (U. S. Govt. Printing Office).

Jones, L. M., and Faure, G., 1972. The strontium isotope geochemistry of Great Salt Lake, Utah. Geol. Soc. Am. Bull., 83:1875-1880.

Kastens, K. A., Mascle, J., et al., 1987. Proc. ODP, Init. Repts., 107: College Station, TX (Ocean Drilling Program.

Kay, R. L. F., and Darbyshire, D. P. F., 1986. A strontium isotope study of groundwater-rock interaction in the carnmenellis granite. Int. Symp. on Water-Rock Interaction, Reykjavik, Iceland, 329-332.

Koepnick, R. B., Burke, W. H., Denison, R. E., Hetherington, E. A., Nelson, H. F., Otto, J. B., and Waite, L. E., 1985. Construction of the seawater ${ }^{87} \mathrm{Sr} /{ }^{86} \mathrm{Sr}$ curve for the Cenozoic and Cretaceous: supporting data. Chem Geol., 58:55-81.

Kushnir, J., 1982. The composition and origin of brines during the Messinian desiccation event in the Mediterranean basin as deduced from concentrations of ions coprecipitated with gypsum and anhydrite. Chem. Geol., 35:333-350.

Land, L. S., 1987. Louann salt geochemistry: A preliminary synthesis. Soc. Econ. Pal. Min. Annual Midyear Meeting, Austin, Texas, IV: 46. Abstract

Matter, A., Peters, T., and Ramseyer, K., $1987 .{ }^{87} \mathrm{Sr} /{ }^{86} \mathrm{Sr}$-Verhältnisse und $\mathrm{Sr}$-Gehalte von Tiefengrundwässern, Mineralien sowie Gesteinen aus dem Kristallin und der Trias der Nordschweiz. Eclogae geol. Helv., 80:579-592.

McCrea, J. M., 1950. The isotopic chemistry of carbonates and paleotemperature scale. J. Chem. Phys., 18:849-857.
McKenzie, J. A., Hodell, D. A., Mueller, P. A., and Müller, D. W., in press. Application of strontium isotopes to late Miocene-early Pliocene stratigraphy. Geology.

McNutt, R. H., Frape, S. K., and Fritz, P., 1984. Strontium isotope composition of some brines from the Precambrian Shield of Canada. Isotope Geosci., 2:205-215.

Morrow, D. W., 1982. Diagenesis 2. Dolomite-Part 2, Dolomitization models and ancient dolostones. Geosci. Canada, 9:95-107.

Müller, D. W., and Hsü, K. J., 1987. Event stratigraphy and paleoceanography in the Fortuna Basin (SE Spain): A scenario for the Messinian salinity crisis. Paleoceanography, 2:679-696.

Neev, D., and Emery, K. O., 1967. The Dead Sea. Depositional processes and environments of evaporites. Israel Geol. Survey Bull., 41: 147.

Palmer, M. R., and Elderfield, H., 1985. Sr isotope composition of sea water over the past $75 \mathrm{Myr}$. Nature, 314:526-528.

Pierre, C., 1974. Contribution a l'étude sèdimentologique et isotopique des èvaporites messiniennes de la Mèditerranèe; implications gèodynamiques [Ph.D. dissert.]. Paris.

1982. Teneurs en isotopes stables $(180,2 \mathrm{H}, 13 \mathrm{C}, 34 \mathrm{~S})$ et conditions de genèse des evaporites marines: Application a quelques milieux actuels et au Messinien de la Mèditerranèe [Ph.D. dissert.]. University of Paris-south, Orsay.

Pierre, C. and Fontes, J. C., 1978. Isotope composition of Messinian sediments from the Mediterranean Sea as indicators of paleoenvironments and diagenesis. In Hsü, K. J., Montadert, L., et al., 1978. Init. Repts. DSDP, 42, Pt. 1: Washington (U. S. Govt. Printing Office), 635-650.

Richter, F. M., and DePaolo, D. J., 1987. Numerical models for diagenesis and the Neogene $\mathrm{Sr}$ isotopic evolution of seawater from DSDP Site 590B. Earth Planet, Sci, Letts., 83:27-38.

Ricchiuto, T. E., and McKenzie, J. A., 1978. Stable isotopic investigation of Messinian sulfate samples from DSDP Leg 42A, Eastern Mediterranean Sea. In Hsü, K. J., Montadert, L., et al., 1978. Init. Repts. DSDP, 42, Pt. 1: Washington (U. S. Govt. Printing Office), 657-660.

Ruggieri, G., 1967. The Miocene and later evolution of the Mediterranean Sea. In Adams and Ager (Eds.), Aspects of Tethyan Biogeography. Syst. Publ.: 7:238.

Ryan, W.B.F., Hsü, K. J., et al., 1973. Init. Repts. DSDP, 13: Washington (U. S. Govt. Printing Office).

Saller, A., 1984. Petrologic and geochemical constraints on the origin of subsurface dolomite, Eniwetok Atoll: An example of dolomitization of normal seawater. Geology, 12:217-220.

Schreiber, B. C., Friedman, G. H., Decima, A., and Schreiber, E., 1976. Depositional environments of Upper Miocene (Messinian) evaporite deposits of the Sicilian Basin. Sedimentology, 23,255-270.

Staudigel, H., Doyle, P., and Zindler, A., 1985. Sr and Nd isotope systematics in fish teeth. Earth Planet. Sci. Lett., 76:35-44.

Swart, P. K., Ruiz, J., and Holmes, C. W., 1987. Use of strontium isotopes to constrain the timing and mode of dolomitization of upper Cenozoic sediments in a core from San Salvador, Bahamas. Geology, 15:262-265.

Tarnoff, S. R. and Hurst, R. W., 1986. Anomalous strontium isotopic compositions in the Recent seawater and marine carbonates from the Gulf of California. In Geol. Soc. Am. Abstr. Programs, 98:769. (Abstract.)

Teller, T. T., Bowler, J. M., and Macumber, P. G., 1982. Modern sedimentation and hydrology in Lake Tyrell, Victoria. J. Geol. Soc. Aust., 29:159-175.

Turekian, K. K., 1969. In Wedepohl, K. H. (Ed.) Handbook of Geochemistry, Heidelberg (Springer), 6:297-323.

Usdowski, E., 1973. Das geochemische Verhalten des Strontiums bei der Genese und Diagenese von Ca-Karbonat- und Ca-Sulfat-Mineralien. Contrib. Mineral. Petrol., 38:177-195.

Zierenberg, R. A., and Shanks III, W. C., 1986. Isotopic constraints on the origin of the Atlantis II, Suakin and Valdivia brines, Red Sea. Geochim, Cosmochim. Acta, 50:2205-2214.

Date of initial receipt: 8 February 1988

Date of acceptance: 27 January 1989

Ms 107B-194 